Check for updates

Cite this: RSC Adv., 2018, 8, 15009

Received 17th January 2018

Accepted 3rd April 2018

DOI: $10.1039 / c 8 r a 00465 j$

rsc.li/rsc-advances

\section{Development of 2-arylbenzo[h]quinolone analogs as selective CYP1B1 inhibitors $\uparrow$}

\author{
Jinyun Dong, (D) Zengtao Wang, Qingqing Meng, Qijing Zhang, Guang Huang, \\ Jiahua Cui* and Shaoshun Li*
}

The CYP1B1 enzyme is regarded as a potential target for cancer prevention and therapy. Based on the structure of $\alpha$-naphthoflavone (ANF), diverse 2 -arylbenzo[h]quinolone derivatives were designed, synthesized and evaluated as selective CYP1B1 inhibitors. Compared with ANF, although few of the title compounds possessed comparable or slightly higher CYP1B1 inhibitory activity, these compounds displayed a significantly increased selectivity toward CYP1B1 over CYP1A2. Among them compounds 5e, $5 \mathrm{~g}$ and $5 \mathrm{~h}$ potently inhibited the activity of CYP1B1 with $I C_{50}$ values of 3.6, 3.9 and $4.1 \mathrm{nM}$ respectively, paralleled by an excellent selectivity profile. On the basis of predicted clog $P$ values, these target compounds may exhibit improved water-solubility compared to ANF. In particular, $5 \mathrm{~h}$ showed a great superiority in the reversal of CYP1B1-mediated docetaxel resistance in vitro. The current study may serve as a good starting point for the further development of more potent as well as specific CYP1B1 inhibitors capable of reversing CYP1B1-mediated anticancer-drug resistance.

\section{Introduction}

Human cytochrome P450 enzymes (CYPs) are composed of different families of hemeproteins that play a predominant role in the oxidative metabolism of both exogenous and endogenous substances. The CYP1 subfamily of enzymes (CYP1s) contains three extensively studied members, CYP1A1, CYP1A2, and CYP1B1, due to their critical roles in pro-carcinogen-elicited tumorigenesis and inducing drug resistance. ${ }^{1}$ They are expressed in a tissue-specific manner, and are induced via the aryl hydrocarbon receptor (AhR), which is a ligand-activated transcription factor. ${ }^{2}$ Planar aromatic molecules such as 2,3,7,8-tetra-chlorodibenzo- $p$-dioxin (TCDD) and 7,12-dimethylbenz $[a]$ anthracene (DMBA) have been identified as potent AhR ligands that induce the overexpression of CYP1 enzymes. ${ }^{3-5}$ A large number of pro-carcinogens such as polycyclic aromatic hydrocarbons (PAHs), polyhalogenated aromatic hydrocarbons (PHAHs), aryl amines, heterocyclic aryl amines and estrogens can be converted into cytotoxic, mutagenic and carcinogenic chemicals in the presence of overexpressed CYP1 enzymes. ${ }^{1}$

Among the three isoforms mentioned above, CYP1B1 is the most promising target. On one hand, it has been regarded as an important enzyme in the carcinogenic action of $17 \beta$-estradiol $\left(E_{2}\right)$ by catalyzing the hydroxylation of $E_{2}$ at C-4 regiospecifically to generate the carcinogenic form 4-hydroxy estradiol $\left(4-\mathrm{OHE}_{2}\right)$.

School of Pharmacy, Shanghai Jiao Tong University, 800 Dongchuan Road, Shanghai, China.E-mail: cpucjh@sjtu.edu.cn; ssli@sjtu.edu.cn; Fax: +862134204775; Tel: +86 2134204775

$\dagger$ Electronic supplementary information (ESI) available. See DOI: 10.1039/c8ra00465j
Subsequent oxidation of $4-\mathrm{OHE}_{2}$ to $\mathrm{E}_{2}-3,4$-quinone promotes the formation of a covalent quinone-DNA adduct, which is responsible for estrogen-related carcinogenesis. Conversely, the other two members of the CYP1 family are prone to generate 2hydroxy estradiol (2- $\mathrm{OHE}_{2}$ ); its further-oxidized product $\mathrm{E}_{2}-2,3-$ quinone has been proven to be non-mutagenic. ${ }^{6,7}$ On the other hand, the overexpressed CYP1B1 isoform can speed up the metabolic inactivation of a structurally diverse range of anticancer drugs, such as docetaxel, doxorubicin, paclitaxel, and mitoxantrone. ${ }^{8}$ As a result, the cellular efficacy of cytotoxic drugs is decreased and cancer cells will eventually develop resistance to these chemotherapeutic agents. Many studies have confirmed that the CYP1B1 isoform is significantly and consistently overexpressed in a wide variety of tumor tissues such as mammary, prostate, ovary, uterus, pituitary, and also in skin and lung cancers, while it is expressed at very low levels or not at all in normal tissues. ${ }^{9-12}$ Hence, selective inhibition of this enzyme will have a great influence on cancer prevention and the reversal of drug resistance.

$\alpha$-Naphthoflavone (ANF), a synthetic flavonoid, bears a phenyl ring annulated at C-7,8 of the A-ring of flavone. It has been recognized as a potent CYP1 inhibitor which exhibits strong inhibitory effects on recombinant human CYP1B1 and CYP1A2 with $\mathrm{IC}_{50}$ values of 5 and $6 \mathrm{nM}$ respectively, but to a much lesser extent on CYP1A1 (with an $\mathrm{IC}_{50}$ value of $\left.60 \mathrm{nM}\right) .{ }^{13}$ Evidence has accumulated during the past several years that exposure to ANF can reduce drug resistance and enhance the sensitivity of CYP1B1-expressing cell lines to anticancer drugs. ${ }^{\mathbf{1 4 , 1 5}}$ However, its further development is still restricted due to its poor water solubility and very limited selectivity 
toward CYP1B1 over CYP1A2 ${ }^{8}$ From the X-ray crystallographic structures of CYP1 enzymes and ANF, it can be observed that the amino acid sequences and the orientations of ANF in the binding cavity are different among CYP1 members. ${ }^{16-18}$ Asp333 on the I helix of CYP1B1 is adjacent to the oxygen atom in the Cring of ANF, with a short distance of $4.6 \AA$, while Asp320 on the I helix of CYP1A1 or CYP1A2 is close to the carbonyl oxygen atom of ANF. Inspired by a hypothesis that an alkaline group can be introduced at a suitable location to enhance interactions with the acidic amino acid Asp333, replacement of the oxygen atom on the C-ring of ANF with a bioisosteric hydrophilic imino group was carried out with the aim to improve its selectivity towards CYP1B1 and water solubility. In continuation of our previous work in this area, ${ }^{8}$ we synthesized and biologically evaluated different classes of 2 -arylbenzo[ $h]$ quinolones as novel CYP1 inhibitors (Fig. 1).

\section{Results and discussion}

\subsection{Synthesis}

The 2-aryl-2,3-dihydrobenzo[ $h]$ quinolin-4(1H)-ones 1a-d and their 3-hydroxy derivatives $\mathbf{2 a , b}$ were prepared from 1-nitronaphthalene (6) (Scheme 1). Treatment of $\mathbf{6}$ with ethyl cyanoacetate and $\mathrm{KCN}$ in the presence of $\mathrm{KOH}$ in DMF at $55^{\circ} \mathrm{C}$ for $36 \mathrm{~h}$ formed an intermediate, which was followed by hydrolysis to furnish 1-amino-2-naphthonitril (7) in 40\% yield. ${ }^{19}$ Several attempts to improve the yield of compound 7 including variation of time, temperature and replacement of ethyl cyanoacetate with dicyanomethane were made by our research groupunfortunately the yield was not obviously improved. Subsequently, intermediate 7 was reacted with methylmagnesium iodide, and this was followed by a hydrolysis reaction to give 1amino-2-acetylnaphthalene $(\mathbf{8}) .^{\mathbf{2 0}}$ The 2 -aminochalcone derivatives 10a-d were obtained by the condensation of $\mathbf{8}$ with benzaldehydes 9a-d under alkaline conditions in THF. On one hand, the cyclizations of 10a-d to the corresponding 2-aryl-2,3-dihydrobenzo[ $h]$ quinolin-4(1H)-ones 1a-d were accomplished by the addition of antimony trichloride $\left(\mathrm{SbCl}_{3}\right)$ in $\mathrm{CH}_{3} \mathrm{CN} .{ }^{21}$ Considering its toxicity, we also made efforts in exploring safe catalysts such as $\mathrm{ZnCl}_{2}$ and $\mathrm{AlCl}_{3}$, nevertheless, none of these Lewis acids were identified as an efficient catalyst for this intramolecular aza-Michael reaction. On the other hand, oxidation of $\mathbf{1 0 a - d}$ by alkaline hydrogen peroxide afforded the stable 2-aminochalcone epoxide derivatives 11a,b in very good yields, ${ }^{22}$ which were cyclized to 3-hydroxy-2-aryl-2,3-dihydrobenzo[ $h]$ quinolin$4(1 H)$-ones $2 \mathbf{a}$,b via an intramolecular nucleophilic reaction by addition of a catalytic amount of $\mathrm{AlCl}_{3}$. It is of note that dilute $\mathrm{HCl}$ and HOAc as catalysts were also used in this reaction, but we failed to obtain any title compound.

For the preparation of 3-hydroxy-2-arylbenzo[h]quinolin$4(1 H)$-ones 3a-d, we used the synthetic strategy described in Scheme 2. 1-Amino-2-naphthonitril (7) was hydrolyzed with $20 \% \mathrm{NaOH}$ to provide the corresponding L-amino-2-naphthoic acid (12) in $62 \%$ yield. Treatment of 12 with 2-bromo-1arylethan-1-ones 13a-d in the presence of $\mathrm{K}_{2} \mathrm{CO}_{3}$ in DMF gave intermediates 14a-d in excellent yields, which was followed by a cyclization under acidic conditions using polyphosphoric acid (PPA) at $130{ }^{\circ} \mathrm{C}$ to yield title compounds 3a-d.

The 2-arylbenzo[h]quinolin-4(1H)-one series $\mathbf{3 e}$ and $\mathbf{5 a - j}$ was prepared using the synthetic method described in Scheme 3. Ethyl benzoylacetate derivatives $\mathbf{1 7 a - j}$ as key intermediates were obtained by the reaction of potassium ethyl malonate with different benzoic acids $\mathbf{1 6 a - j}$ in the presence of $1,1^{\prime}$-carbonyl-bis- $1 H$-imidazole (CDI) in an acceptable yield. ${ }^{23}$ 1-Naphthylamine (18) was commercially available and its derivative $\mathbf{2 0}$ was prepared effectively from the starting material 19 using our previously reported method. ${ }^{24}$ The condensation reaction of these naphthylamine derivatives with $\mathbf{1 7} \mathbf{a}-\mathbf{j}$ in the presence of PPA provided title compounds in low yields. It is interesting to note that $\mathbf{4 a}$, the isomer of 3e, also could be isolated in high yield during the process for the preparation of 3e. Lastly, methylation of $4 \mathbf{a}$ was carried out using methyl iodide under alkaline conditions to give $\mathbf{4 b}$ in high yield.

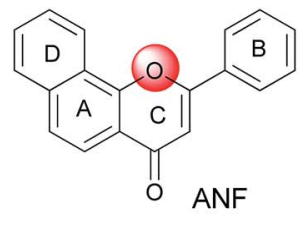

Lead compound

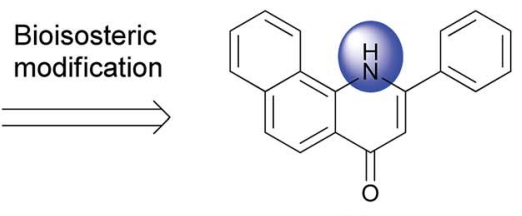

Structural extension

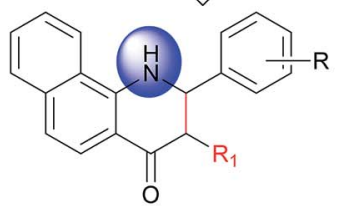

$\mathrm{R}=$ Halogen or Alkoxy $\mathrm{R}_{1}=\mathrm{H}$ or $\mathrm{OH}$
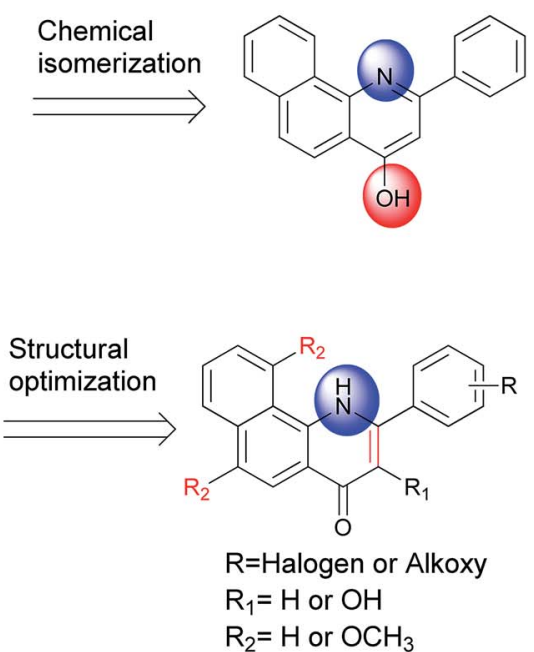

Fig. 1 Design of a series of 2-arylbenzo[h]quinolones as CYP1 inhibitors. 


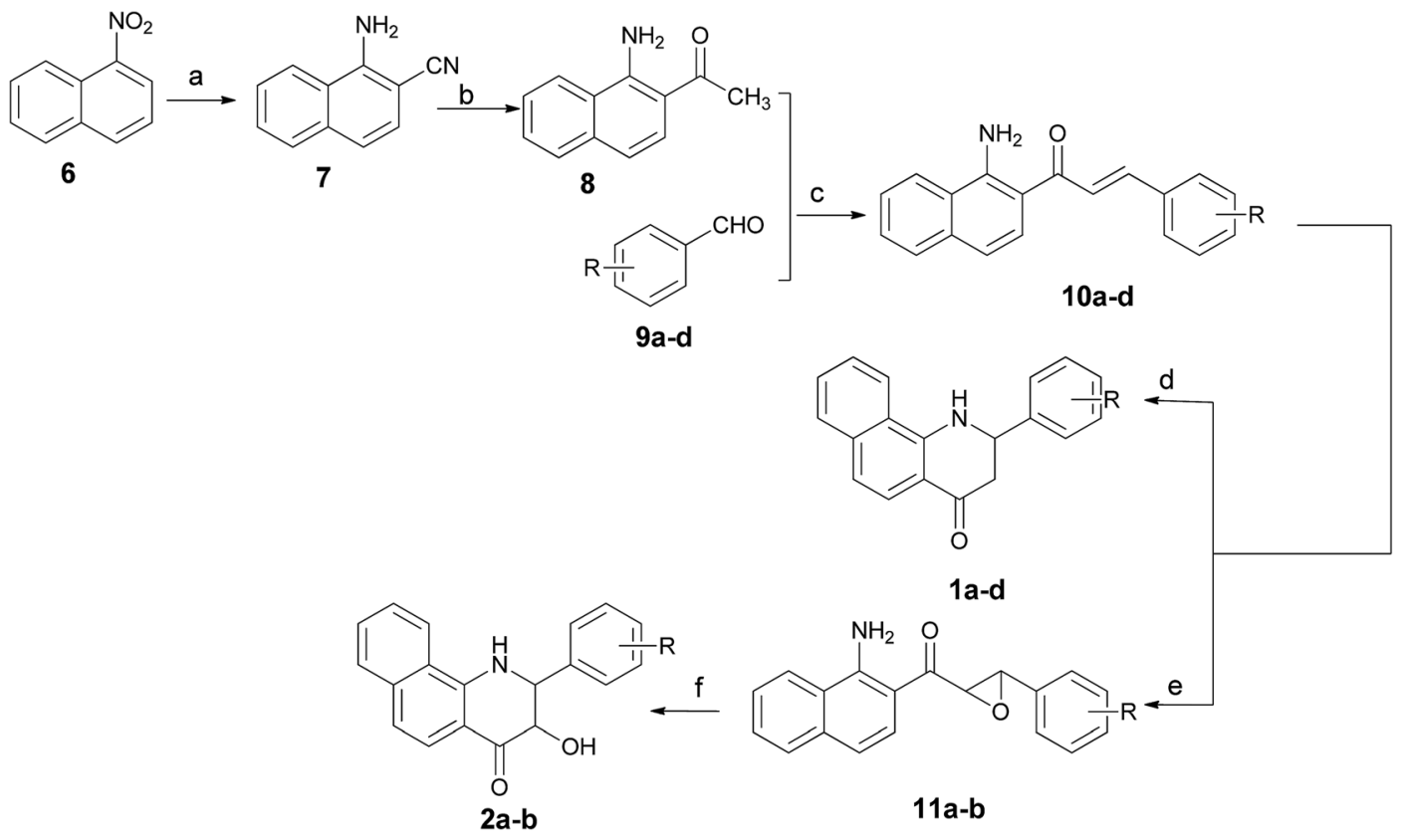

Scheme 1 Synthetic routes for compounds $1 \mathrm{a}-\mathrm{d}$ and $2 \mathrm{a}, \mathrm{b}$. Reagents and conditions: (a) $\mathrm{KCN}, \mathrm{NCCH} \mathrm{COOEt} \mathrm{KOH}, \mathrm{DMF}, 60^{\circ} \mathrm{C}$ for $24 \mathrm{~h}$ and then reflux in $\mathrm{NaOH}-\mathrm{H}_{2} \mathrm{O}$ (5\%); (b) $\mathrm{Mg}, \mathrm{CH}_{3} \mathrm{l}, \mathrm{Et}_{2} \mathrm{O}, \mathrm{N}_{2}, \mathrm{HCl}\left(2 \mathrm{~N}\right.$ ); (c) $\mathrm{CH}_{3} \mathrm{ONa}$, THF; (d) $\mathrm{SbCl}_{3}, \mathrm{CH}_{3} \mathrm{CN}, 80{ }^{\circ} \mathrm{C}$; (e) $\mathrm{H}_{2} \mathrm{O}_{2}, \mathrm{NaOH}, \mathrm{MeOH}^{\circ}$ (f) $\mathrm{AlCl}$, $\mathrm{DCM}$.

\subsection{CYP1 enzyme inhibitory activities}

The ethoxyresorufin-O-deethylase (EROD) assay, a widely used method for the evaluation of CYP1 activities, was used to determine the inhibitory abilities of these synthesized compounds toward recombinant human CYP1B1, CYP1A1, and CYP1A2 enzymes. Initially, we synthesized several 2-aryl-2,3dihydrobenzo[ $h]$ quinolin-4(1H)-ones and their 3-hydroxy derivatives that were lacking the $\mathrm{C} 2-\mathrm{C} 3$ double bond and/or a hydroxyl group at the C3 position on the C-ring (1a-d and $\mathbf{2 a}, \mathbf{b})$, with the view that this would possibly improve the poor water solubility of ANF by reducing its molecular planarity. The results are presented in Table 1 . Generally, it was observed that all compounds displayed selective inhibition of CYP1B1 over CYP1A1 and CYP1A2, which was consistent with our expectation. However, all of the tested compounds showed moderate to poor inhibitory activities toward CYP1s, and their inhibitory activities decreased dramatically compared to that of ANF. Among them, 1b was identified as the most potent compound in inhibiting CYP1B1 and CYP1A1, with IC $_{50}$ values of 20.2 and $44.6 \mathrm{nM}$ respectively, but was much less effective in inhibiting CYP1A2. However, addition of a hydroxyl group at the C3 position (2b) dramatically reduced the inhibitory effects on CYP1B1 and CYP1A1. On the basis of the results above, we presume that the double bond at the $\mathrm{C} 2-\mathrm{C} 3$ position may be an indispensable structural feature for inhibitory action, while the hydroxyl group at the $\mathrm{C} 3$ position is an unfavorable structural characteristic for exerting an inhibitory effect on CYP1s.

Next we prepared and evaluated a series of 3-hydroxy-2arylbenzo[h]quinolin-4(1H)-ones 3a-d and a 2-arylbenzo[h]quinolin-4(1H)-one (3e) with a C2-C3 double bond. As can be appreciated from Table 2, the inhibitory activities of compounds 3a-d against CYP1B1 were significantly higher than those against CYP1A2 $\left(\mathrm{IC}_{50}>5000 \mathrm{nM}\right)$. Also, they poorly inhibited the catalytic activity of CYP1A1. It seems that substituents on the B-ring exert no obvious effect on CYP1 inhibition, since compounds $\mathbf{3 b} \mathbf{b}-\mathbf{d}$ displayed similar potencies<smiles>[R]c1ccc(C(=O)CBr)cc1</smiles>

Scheme 2 Synthetic routes for compounds $3 a-d$. Reagents and conditions: (a) $\mathrm{NaOH}$ solution (20\%), EtOH, reflux, conc. $\mathrm{HCl}$ (b) $\mathrm{K}_{2} \mathrm{CO}$, $\mathrm{DMF}$, $90^{\circ} \mathrm{C}$; (c) PPA, $120^{\circ} \mathrm{C}$. 


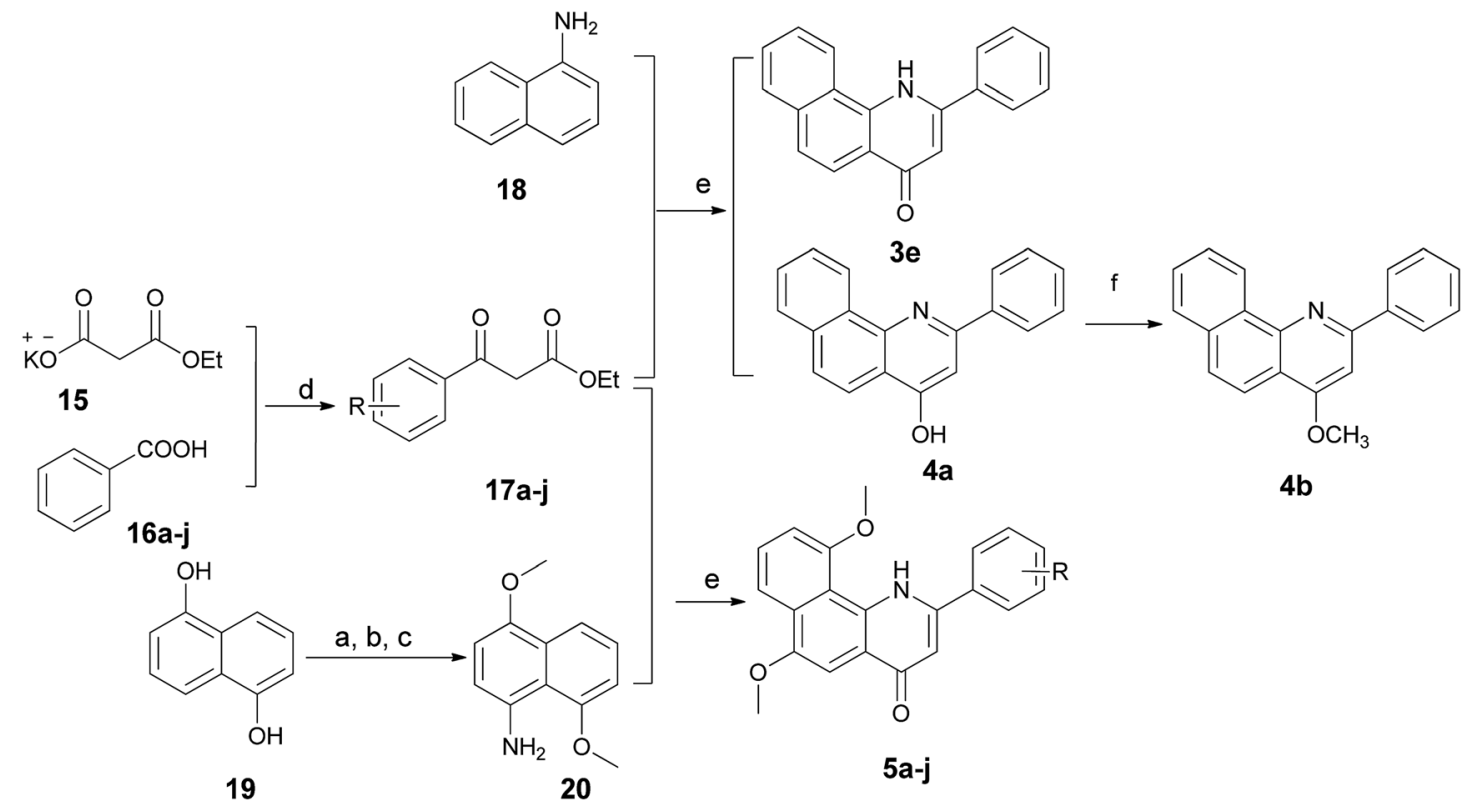

Scheme 3 Synthetic routes for compounds $3 \mathrm{e}, 4 \mathrm{a}, 4 \mathrm{~b}$ and $5 \mathrm{a}-\mathrm{j}$. Reagents and conditions: (a) $\left(\mathrm{CH}_{3}\right)_{2} \mathrm{SO}_{4}, \mathrm{NaOH}, \mathrm{THF}$ (b) $\mathrm{HNO}$, $\mathrm{HOAc}$; (c) $\mathrm{NH}_{2} \mathrm{NH}_{2}-\mathrm{H}_{2} \mathrm{O}, \mathrm{Zn}$; (d) CDI, $\mathrm{MgCl}_{2}$, TEA, THF; (e) PPA, $130{ }^{\circ} \mathrm{C}$; (f) $\mathrm{NaH}, \mathrm{CH}_{3}$ l, DMF.

against the CYP1s to that of 3a. It was noteworthy that 3a, with a double bond introduced at the $\mathrm{C} 2-\mathrm{C} 3$ position, was 3 times more potent than 2a in the CYP1B1 enzymatic inhibition assay. Compound 3e, a 3-dehydroxylated compound of 3a, exhibited an increased ability to inhibit CYP1B1, with an $\mathrm{IC}_{50}$ value of $17.3 \mathrm{nM}$, and is about $5-8$ times more potent than $\mathbf{3 a}$ and $\mathbf{1 a}$. However, comparison of the activities of $3 \mathbf{e}$ and ANF against the CYP1s showed that replacement of the oxygen atom in ANF with a nitrogen atom in $\mathbf{3 e}$ led to a loss of inhibitory potency. This result may be explained by the fact that introduction of a nitrogen atom resulted in a reduced planarity of the backbone of ANF. Interestingly, compared with ANF this compound had an excellent selectivity profile, as it was 27.9-fold selective for CYP1B1 over CYP1A2, suggesting that $3 \mathbf{e}$ is a promising lead compound for the further development of selective and potent CYP1B1 inhibitors. Together with the data presented in Tables 1 and 2, it can be concluded that the $\mathrm{C} 2-\mathrm{C} 3$ double bond contributes to improving the inhibitory efficiency toward CYP1 enzymes, while the C3-hydroxyl group results in a loss in potency. To our surprise, compound $4 \mathbf{a}$ as a chemical isomer of 3e could strongly inhibit the activities of CYP1B1 and CYP1A1 with $\mathrm{IC}_{50}$ values of 7.6 and $18.5 \mathrm{nM}$ respectively, and was 2 and 5

Table 1 Inhibitory potency of 2-aryl-2,3-dihydrobenzo[h]quinolin-4(1H)-ones 1a-d and their 3-hydroxy derivatives 2a,b against CYP1B1, 1A1, and $1 \mathrm{~A} 2$<smiles>[R]c1cccc(C2Nc3c(ccc4ccccc34)C(=O)C2[R])c1</smiles>

1a-d; 2a-b

\begin{tabular}{|c|c|c|c|c|c|c|c|}
\hline \multirow[b]{2}{*}{ Compound } & \multirow[b]{2}{*}{ R1 } & \multirow[b]{2}{*}{$\mathrm{R}$} & \multicolumn{3}{|c|}{$\mathrm{IC}_{50}$ values $(\mathrm{nM})$} & \multicolumn{2}{|l|}{$\mathrm{IC}_{50}$ ratio } \\
\hline & & & 1B1 & 1A1 & $1 \mathrm{~A} 2$ & 1A1/1B1 & 1A2/1B1 \\
\hline $1 \mathbf{a}$ & $\mathrm{H}$ & $\mathrm{H}$ & 131.4 & 404.6 & 952.8 & 3.1 & 7.3 \\
\hline $1 \mathrm{~b}$ & $\mathrm{H}$ & $3,4,5-\mathrm{TriOCH}_{3}$ & 20.2 & 44.6 & $>5000$ & 2.2 & $>247.5$ \\
\hline $1 \mathrm{c}$ & $\mathrm{H}$ & $o-\mathrm{F}$ & 139.3 & 577.5 & 1097 & 4.1 & 7.9 \\
\hline 1d & $\mathrm{H}$ & $m-\mathrm{F}$ & 98.6 & 493.2 & 1045 & 5.0 & 10.6 \\
\hline $2 \mathbf{a}$ & $\mathrm{OH}$ & $\mathrm{H}$ & 259.6 & 587.9 & 1411 & 2.3 & 5.4 \\
\hline $2 \mathbf{b}$ & $\mathrm{OH}$ & $3,4,5-\mathrm{TriOCH}_{3}$ & 302.5 & 1161 & $>5000$ & 3.8 & $>16.5$ \\
\hline ANF & - & - & 5.6 & 62.8 & 14.1 & 11.2 & 2.5 \\
\hline
\end{tabular}


Table 2 Inhibitory potency of 3-hydroxy-2-arylbenzo[h]quinolin$4(1 H)$-ones 3a-d, 2-arylbenzo[h]quinolin-4(1H)-one 3eand its chemical isomers $4 a, b$ against CYP1B1, CYP1A1, and CYP1A2
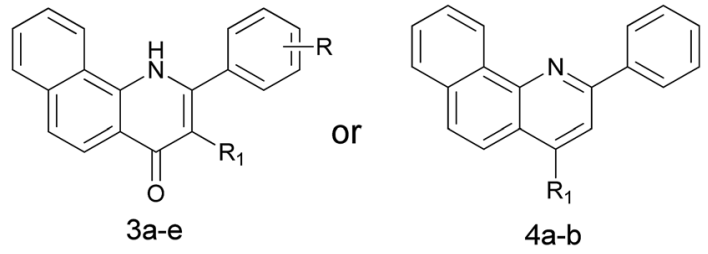

\begin{tabular}{|c|c|c|c|c|c|c|c|}
\hline \multirow[b]{2}{*}{ Compound } & \multirow[b]{2}{*}{$\mathrm{R} 1$} & \multirow[b]{2}{*}{$\mathrm{R}$} & \multicolumn{3}{|c|}{$\mathrm{IC}_{50}$ values $(\mathrm{nM})$} & \multicolumn{2}{|l|}{$\mathrm{IC}_{50}$ ratio } \\
\hline & & & 1B1 & 1A1 & $1 \mathrm{~A} 2$ & 1A1/1B1 & 1A2/1B1 \\
\hline $3 \mathbf{a}$ & $\mathrm{OH}$ & $\mathrm{H}$ & 86.7 & 897.7 & $>5000$ & 10.4 & $>57.7$ \\
\hline $3 \mathbf{b}$ & $\mathrm{OH}$ & $o-\mathrm{F}$ & 85.9 & 1783 & $>5000$ & 20.8 & $>58.2$ \\
\hline $3 \mathbf{c}$ & $\mathrm{OH}$ & $p-\mathrm{OH}$ & 141.7 & 525.1 & $>5000$ & 3.7 & $>35.3$ \\
\hline 3d & $\mathrm{OH}$ & $p-\mathrm{F}$ & 93.3 & 333.5 & $>5000$ & 3.6 & $>53.6$ \\
\hline $3 e$ & $\mathrm{H}$ & $\mathrm{H}$ & 17.3 & 103.2 & 483.5 & 6.0 & 27.9 \\
\hline $4 a$ & $\mathrm{OH}$ & - & 7.6 & 18.5 & 146.9 & 2.4 & 19.3 \\
\hline $4 \mathrm{~b}$ & $\mathrm{OCH}_{3}$ & - & $\mathrm{NI}^{a}$ & NI & NI & - & - \\
\hline
\end{tabular}

times more potent than 3e. Additionally, it showed 19.3-fold selectivity for CYP1B1 over CYP1A2 (with an $\mathrm{IC}_{50}$ value of 146.9 nM for CYP1A2). However, when this hydroxyl group was methylated, the obtained compound $\mathbf{4 b}$ was no longer a CYP1 inhibitor since its concentration-dependent activity was not observed. It can be speculated that the hydroxyl group may form an essential hydrogen bond with other residue(s).

The crystal structure of human CYP1B1 with ANF disclosed that $\pi-\pi$ stacking between the naphthalene part of ANF and Phe231 plays an influential role in maintaining the high binding affinity of ANF with human CYP1B1. ${ }^{16}$ Considering that enhancing the electron density of the naphthalene part will intensify the $\pi-\pi$ stacking interaction with Phe231, a series of 6,10-dimethoxy-2-arylbenzo[ $h]$ quinolin-4(1H)-ones were synthesized. The results are summarized in Table 3. In general, it was observed that the potency loss caused by replacing the oxygen atom in ANF with a nitrogen atom was able to be partially or completely restored by introducing two methoxy groups on the naphthalene moiety. The resulting inhibitors (5a-j) suppressed the CYP1 activities in a substituentdependent manner. Consistent with our previous results, all of the inhibitors except 5a, 5b and 5d showed high selectivity toward CYP1B1 over CYP1A1 and CYP1A2. Among them, compounds $\mathbf{5 e}$ and $\mathbf{5} \mathbf{g}$ exhibited the highest potency for inhibition of CYP1B1 with $\mathrm{IC}_{50}$ values of 3.6 and $3.9 \mathrm{nM}$ respectively, and were more potent than ANF. Furthermore, these two compounds also displayed very high selectivity toward CYP1B1 over CYP1A2 (more than 163 and 540 times higher than those observed for CYP1A2, respectively), more than 65 and 216 times higher than that of ANF. Besides, compounds $\mathbf{5 c}, \mathbf{5 f}$ and $\mathbf{5 h}$ displayed similar potencies and notable selectivity against CYP1B1 to those of $5 \mathbf{e}$ and $\mathbf{5 g}$ with $\mathrm{IC}_{50}$ values of $7.8,7.1$ and $4.1 \mathrm{nM}$, respectively. Conversely, when three methoxy groups
Table 3 Inhibitory potency of 6,10-dimethoxy-2-arylbenzo[h]quinolin-4(1H)-ones 5a-j against CYP1B1, CYP1A1, and CYP1A2<smiles>[R]c1ccc(-c2cc(=O)c3cc(OC)c4cccc(OC)c4c3[nH]2)cc1</smiles>

$5 a-j$

\begin{tabular}{|c|c|c|c|c|c|c|}
\hline \multirow[b]{2}{*}{ Compound } & \multirow[b]{2}{*}{$\mathrm{R}$} & \multicolumn{3}{|c|}{$\mathrm{IC}_{50}$ values $(\mathrm{nM})$} & \multicolumn{2}{|c|}{$\mathrm{IC}_{50}$ ratio } \\
\hline & & 1B1 & $1 \mathrm{~A} 1$ & $1 \mathrm{~A} 2$ & 1A1/1B1 & 1A2/1B1 \\
\hline $5 \mathbf{a}$ & $\mathrm{H}$ & 16.6 & 12.6 & 147.6 & 0.8 & 8.9 \\
\hline $5 b$ & $o-\mathrm{F}$ & 27.9 & 26.4 & 174 & 0.9 & 6.2 \\
\hline $5 c$ & $m-\mathrm{F}$ & 7.8 & 39.3 & 330.9 & 5.0 & 42.4 \\
\hline $5 d$ & $m-\mathrm{Cl}$ & 27.6 & 29.4 & 84.5 & 1.1 & 3.1 \\
\hline $5 e$ & $m-\mathrm{Br}$ & 3.6 & 19.8 & 587.6 & 5.5 & 163.2 \\
\hline $5 f$ & $m-\mathrm{OCH}_{3}$ & 7.1 & 35.8 & 190.1 & 5.0 & 26.8 \\
\hline $5 g$ & $p-\mathrm{F}$ & 3.9 & 10.5 & 2107 & 2.7 & 540.3 \\
\hline $5 \mathrm{~h}$ & $p-\mathrm{OCH}_{3}$ & 4.1 & 64.7 & $>5000$ & 15.8 & $>1219.5$ \\
\hline $5 \mathbf{i}$ & $p-\mathrm{CF}_{3}$ & 34.4 & 300.4 & 1337 & 8.7 & 38.9 \\
\hline $5 \mathbf{j}$ & $3,4,5-\mathrm{TriOCH}_{3}$ & 163.9 & 809 & $>5000$ & 4.9 & $>30.5$ \\
\hline
\end{tabular}

were introduced into the B-ring, the resulting compound $\mathbf{5 j}$ suffered dramatic potency losses in CYP1 inhibitory activities. This might be due to the fact that the substituted groups can form steric clashes which affect $5 \mathbf{j}$ binding to the active site cavities of CYP1 enzymes with a suitable conformation.

As shown in Fig. 2, on the basis of the inhibitory potency and selectivity of the aforementioned 2-arylbenzo[h]quinolones as CYP1B1 inhibitors, we could draw the following conclusions related to their structure-activity relationships (SARs): (1) introduction of methoxy groups at C- 6 and C-10 on the naphthalene ring greatly increased the inhibitory potency towards CYP1B1; (2) the double bond between C-2 and C-3 contributed to the CYP1B1 inhibitory efficiency; (3) the nitrogen atom in the C-ring caused detrimental effects to the CYP1B1 inhibitory efficiency, but the presence of this atom had somewhat positive effects towards water solubility; (4) introduction of the C-3 hydroxyl group led to a great loss in the potency of CYP1 inhibition; (5) the nature of the substituents on the B-ring also has a strong influence on both CYP1B1 potency and selectivity. Balancing all of the above factors, we have chosen $4 \mathbf{a}$ and $\mathbf{5 e}$ for further molecular docking investigations.

\subsection{Molecular docking}

To investigate the binding modes and rationalize the observed efficiency and selectivity of CYP1 inhibition by compound $\mathbf{4 a}$ and the most potent inhibitor 5e, molecular docking studies were carried out based on the crystal structures 3PM0 and 2HI4, which are from CYP1B1 and CYP1A2 complexed with $\alpha$-naphthoflavone. These two crystal structures were obtained from the Protein Data Bank (RCSB PDB). As shown in Fig. 3(A and B), compound 4 a tightly fitted the active site of CYP1B1, and the 


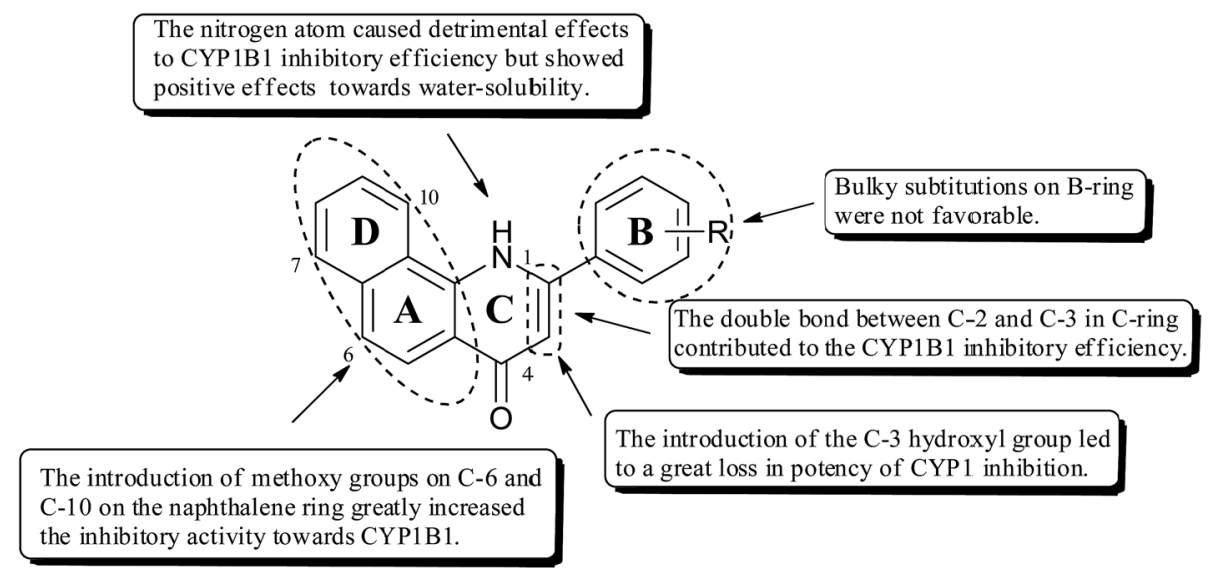

Fig. 2 The SARs for the 2-arylbenzo[h]quinolones.

naphthalene part of this molecule was covered by the phenyl ring of Phe231. In addition to this $\pi-\pi$ stacking interaction, two hydrogen bonds formed by the hydroxyl group of $\mathbf{4 a}$ and Asp326 (with lengths of 1.7 and $2.4 \AA$, respectively) provided an enhanced binding interaction. Also, it offered a reasonable explanation for the phenomenon that methylation of this hydroxyl group led to a dramatically decreased binding affinity of compound $\mathbf{4 b}$ with CYP1B1. However, when $\mathbf{4 a}$ was bound to CYP1A2, no hydrogen bond was formed and its binding affinity arose mainly from the $\pi-\pi$ stacking interaction with Phe226.

Compound 5e, a potent CYP1B1 inhibitor, exhibited excellent selectivity over CYP1A2. Molecular docking provided a plausible explanation for this observation. The results suggested that the binding affinity of this compound to CYP1B1 is much higher than that to CYP1A2 (Fig. 4(A and B)). A hydrogen bond was formed between the carbonyl group of 5e and Asp326 of CYP1B1 with a distance of $3.0 \AA$. Additionally, the alkaline nitrogen atom at the 1-position was adjacent to the acidic amino acid Asp333 with a short distance of $3.6 \AA$, which may play an essential role in improving its binding affinity to CYP1B1. Besides, the $\pi-\pi$ stacking interaction between $\mathbf{5 e}$ and Phe231 also contributed to this binding affinity. However, in the case of CYP1A2, the $\pi-\pi$ stacking interaction between $5 \mathbf{e}$ and Phe226 appeared to be the only direct interaction.

\subsection{Reversal of drug-resistance in MCF-7 cells}

Docetaxel as an effective chemotherapeutic agent has been extensively applied for the treatment of solid tumors in clinics. Nevertheless, after a positive initial response to treatment with these chemotherapeutic drugs, a large proportion of patients relapse. This event is mainly attributed to the intrinsic or acquired drug resistance that greatly compromises the efficacy of anticancer drugs. Previous studies demonstrated that acquired resistance to docetaxel is due in particular to the overexpression of the CYP1B1 enzyme in cancer cells. ${ }^{25}$ Taking into account the fact that the level of CYP1B1 expression is higher in hormone-dependent tissues such as those of the uterus, ovary and breast, ${ }^{26}$ MCF-7 cells were chosen as a model in which CYP1B1 expression was studied. In addition, early research clearly indicated its cytotoxicity can be restored by coincubation of the CYP1B1-overexpressing cells with the CYP1B1 inhibitor ANF. ${ }^{14}$ Stimulated by this finding, we selected six potent inhibitors $\mathbf{4 a}, \mathbf{5 e}, \mathbf{5 g}, \mathbf{5 c}, \mathbf{5 f}$ and $\mathbf{5 h}$ to evaluate their potential to reverse docetaxel resistance in MCF-7 cells.

It is well known that CYP1B1 expression is substantially induced by exposure of the MCF-7 cell line to TCDD. ${ }^{27,28}$ According to the reported methods and our previously presented study, CYP1B1-expressing MCF-7 cells (defined as MCF7/1B1) could be generated by treatment of parental MCF-7 cells

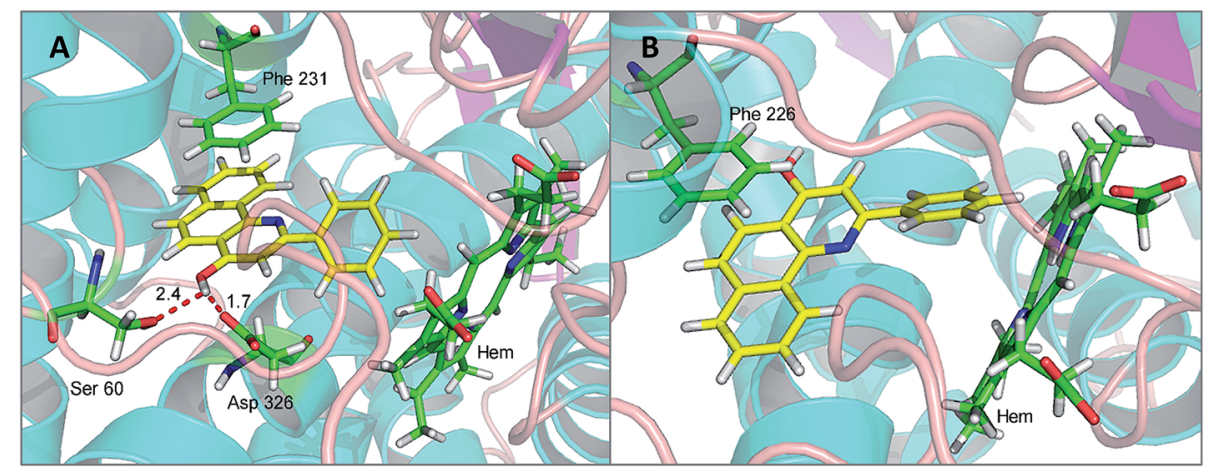

Fig. 3 The binding models: compound 4a with CYP1B1 (A) and CYP1A2 (B). 


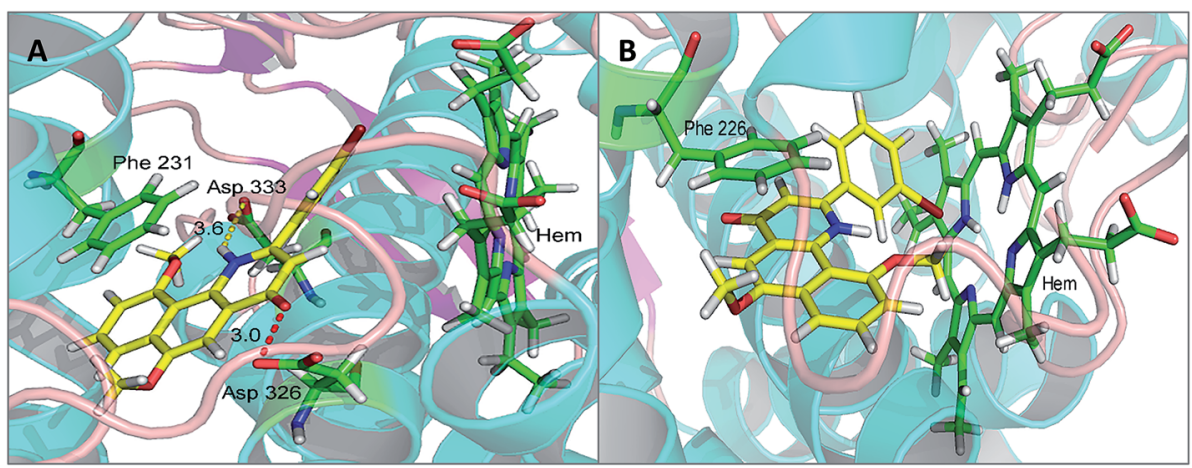

Fig. 4 The binding models: compound 5e with CYP1B1 (A) and CYP1A2 (B) (hydrogen bonding is depicted by red dashed lines, whereas yellow dashed lines represent distance only).

with a low concentration of TCDD for several days. As a result, an enhanced expression of CYP1B1 protein is readily measurable in MCF-7/1B1 cells by western-blot techniques as compared to parental cells. ${ }^{\mathbf{8} 27}$ In this study, MCF-7/1B1 cells were obtained using the same method. Subsequently, the antiproliferation assay was carried out to confirm whether the cells were resistant to docetaxel. Not surprisingly, the results indicated that MCF-7/1B1 cells were 5-fold more resistant to docetaxel than parental MCF-7 cells (the $\mathrm{IC}_{50}$ values for docetaxel in parental MCF-7 cells and MCF-7/1B1 cells were 29.5 and 158.6 $\mu \mathrm{M}$, respectively).

Initially, MCF-7/1B1 cells were treated with $20 \mu \mathrm{M}$ docetaxel alone or in combination with $10 \mu \mathrm{M}$ CYP1B1 inhibitors to preliminarily evaluate the chemosensitization effects of these selected compounds. A percentage inhibition value for each combination was obtained after testing twice, and the results are summarized in Table 4. Generally, the percentage inhibition values for combinations of docetaxel with a CYP1B1 inhibitor were higher than that for treatment with docetaxel alone. To our surprise, among these tested compounds it was $\mathbf{5 h}$-but not the most potent CYP1B1 inhibitor $5 \mathbf{e}$-that was found to be the most promising compound, since it exhibited the highest ability to restore the cytotoxicity of docetaxel. Next, to further confirm whether this effect was caused by the cytotoxicity of 5e, MCF-7/ 1B1 cells were exposed to varying concentrations of $5 \mathbf{e}$ alone, but a significant antiproliferative activity was not observed. A

Table 4 Percentage inhibition values of MCF-7/1B1 cell proliferation with treatment of $10 \mu \mathrm{M}$ CYP1B1 inhibitors and $20 \mu \mathrm{M}$ docetaxel

\begin{tabular}{lll}
\hline Compound & $\operatorname{clog} P^{a}$ & $\begin{array}{l}\% \\
\text { inhibition }\end{array}$ \\
\hline Medium & - & 7.6 \\
$\mathbf{5 h}$ & 3.5 & 33.3 \\
$\mathbf{5 g}$ & 3.7 & 22.5 \\
$\mathbf{5 c}$ & 3.7 & 21.6 \\
$\mathbf{5 e}$ & 4.4 & 26.1 \\
$\mathbf{5 f}$ & 3.5 & 20.1 \\
$\mathbf{4 a}$ & 5.6 & 20.5 \\
ANF & 4.7 & 26.3
\end{tabular}

${ }^{a} \operatorname{clog} P$ values were predicted by ChemBioDraw Ultra 12.0 . plausible explanation was that $\mathbf{5 h}$ may possess a better watersolubility than $\mathbf{5 e}$, as the predicted $\operatorname{clog} P$ value of the former is lower than that of the latter. Finally, the $\mathrm{IC}_{50}$ values of docetaxel in combination with $10 \mu \mathrm{M} 5 \mathbf{h}$ in MCF-7/1B1 cells were determined. As described in Fig. 5 , compound $\mathbf{5 h}$ was shown to be more active than ANF in the reversal of CYP1B1mediated docetaxel resistance. This may be ascribed to a potent CYP1B1 inhibitory activity and an improved watersolubility. Overall, the co-incubation of MCF-7/1B1 cells with $10 \mu \mathrm{M} 5 \mathbf{h}$ caused a complete reversal of docetaxel-resistance, since the $\mathrm{IC}_{50}$ value was decreased to $33.9 \pm 5.1 \mu \mathrm{M}$, which was comparable to that in the parental MCF-7 cells.

\section{Experimental}

\subsection{Chemistry: general procedure}

Chemicals and solvents were used as purchased from commercial suppliers. All anhydrous solvents were dried according to standard methods. Column chromatography was conducted on silica gel (200-300 mesh) from Qingdao Ocean

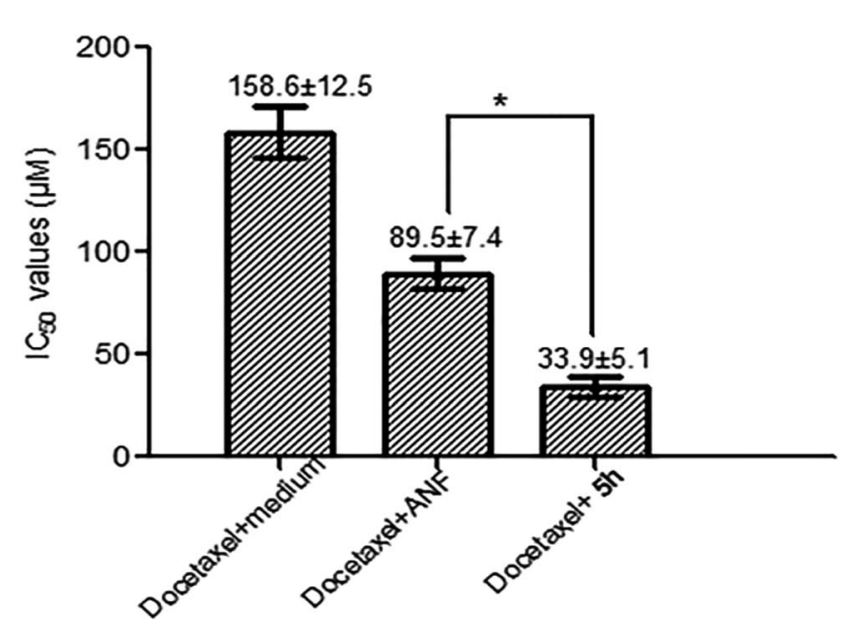

Fig. 5 Reversal of docetaxel resistance in combination with $10 \mu \mathrm{M} 5 \mathrm{~h}$ in MCF-7/1B1 cells. IC 50 values of docetaxel are shown as the mean ( \pm $\mathrm{SD}$ ) of three independent measurements. Significant differences from $I C_{50}$ values are marked with an asterisk $(P<0.01)$. 
Chemical Factory. The ${ }^{1} \mathrm{H}$ and ${ }^{13} \mathrm{C}$ NMR spectra were obtained on a Varian Mercury-300 (400 MHz) spectrometer using DMSO$d_{6}, \mathrm{CDCl}_{3}$ and $\mathrm{CD}_{3} \mathrm{OD}$ as solvents and TMS as an internal standard. All chemical shifts are given in ppm and coupling constants are given in Hz. Mass spectra were recorded with HRMS (ESI, Agilent). Reaction progress was monitored by thinlayer chromatography TLC (silica gel $\mathrm{GF}_{254}$ ) and visualized with UV light (254 or $365 \mathrm{~nm}$ ). The purity of compounds was determined with an Agilent 1260 HPLC system (column: Eclipse plus

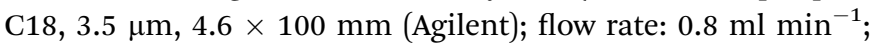
mobile phase: A: $\mathrm{MeOH}, \mathrm{B}: \mathrm{H}_{2} \mathrm{O}$ ).

3.1.1. Procedure for the preparation of 1-amino-2naphthonitril (7). This compound was prepared according to a procedure described in the literature. ${ }^{19}{ }^{1} \mathrm{H}$ NMR $(400 \mathrm{MHz}$, DMSO- $\left.d_{6}\right) \delta 8.33(\mathrm{~d}, J=8.4 \mathrm{~Hz}, 1 \mathrm{H}), 7.80(\mathrm{~d}, J=7.6 \mathrm{~Hz}, 1 \mathrm{H}), 7.59$ $(\mathrm{t}, J=7.3 \mathrm{~Hz}, 1 \mathrm{H}), 7.51(\mathrm{t}, J=7.1 \mathrm{~Hz}, 1 \mathrm{H}), 7.31(\mathrm{~d}, J=8.1 \mathrm{~Hz}$, $1 \mathrm{H}), 7.10(\mathrm{~d}, J=8.3 \mathrm{~Hz}, 1 \mathrm{H}), 6.86(\mathrm{~s}, 2 \mathrm{H})$.

3.1.2. Procedure for the preparation of 1-amino-2acetylnaphthalene (8). Dry magnesium turnings (0.9 g, 37.5 $\mathrm{mmol}$ ) were added to a $250 \mathrm{ml}$, two-necked, round-bottomed flask equipped with one rubber septum and a reflux condenser. The reaction system was stirred under nitrogen, and then a solution of methyl iodide ( $3.5 \mathrm{~g}, 25 \mathrm{mmol}$ ) in anhydrous ethyl ether $(40 \mathrm{ml})$ was added very slowly into the flask through a syringe. The reaction mixture was kept stirring at room temperature for $2 \mathrm{~h}$. Then, a solution of $7(2.5 \mathrm{~g}, 15 \mathrm{mmol})$ in anhydrous ethyl ether $(50 \mathrm{ml})$ was added slowly through a syringe. After the addition was finished, the mixture was heated to reflux for $2 \mathrm{~h}$, and then aqueous $\mathrm{HCl}(2 \mathrm{~N}, 50 \mathrm{ml})$ was added. The resulting mixture was stirred at $30{ }^{\circ} \mathrm{C}$ for $2 \mathrm{~h}$. After the solution was neutralized with aqueous $\mathrm{NaOH}$, the ether layer was separated and the water layer was extracted with EtOAc. The combined organic layers were washed with saturated aqueous $\mathrm{NaCl}$ and then dried over $\mathrm{Na}_{2} \mathrm{SO}_{4}$. The organic layer was concentrated under reduced pressure, and the residue was purified by flash chromatography on silica to give 8 as a yellow solid. ${ }^{1} \mathrm{H}$ NMR (400 MHz, DMSO- $\left.d_{6}\right) \delta 8.58$ (brs, $2 \mathrm{H}$ ), $8.37(\mathrm{~d}, J=8.7 \mathrm{~Hz}, 1 \mathrm{H}), 7.75(\mathrm{t}, J=9.9 \mathrm{~Hz}, 2 \mathrm{H}), 7.60(\mathrm{t}, J=6.0 \mathrm{~Hz}$, $1 \mathrm{H}), 7.48(\mathrm{t}, J=6.0 \mathrm{~Hz}, 1 \mathrm{H}), 7.00(\mathrm{~d}, J=8.8 \mathrm{~Hz}, 1 \mathrm{H}), 2.59(\mathrm{~s}, 3 \mathrm{H})$.

3.1.3. General procedure for the preparation of $10 \mathrm{a}-\mathrm{d}$. To a solution of 8 ( 1 equivalent) in THF was added sodium methoxide (1.1 equivalents) and benzaldehyde 9a-d (1 equivalent). After being stirred overnight at room temperature, THF was evaporated under reduced pressure. The mixture was poured into saturated $\mathrm{NH}_{4} \mathrm{Cl}$, extracted with EtOAc, and washed with saturated $\mathrm{NaHCO}_{3}$ and aqueous NaCl. The combined organic phases were dried over $\mathrm{Na}_{2} \mathrm{SO}_{4}$ and concentrated under reduced pressure. The residue was purified by silica gel column chromatography to give 10a-d as yellow solids. Representative spectral data of 10d, (E)-1-(1-aminonaphthalen-2-yl)-3-(3fluorophenyl)prop-2-en-1-one: ${ }^{1} \mathrm{H}$ NMR (400 $\mathrm{MHz}, \mathrm{CDCl}_{3}$ ) $\delta 7.96(\mathrm{~d}, J=8.7 \mathrm{~Hz}, 1 \mathrm{H}), 7.86(\mathrm{~d}, J=8.9 \mathrm{~Hz}, 1 \mathrm{H}), 7.81(\mathrm{~s}, 1 \mathrm{H})$, $7.76(\mathrm{~d}, J=8.3 \mathrm{~Hz}, 1 \mathrm{H}), 7.74(\mathrm{~s}, 2 \mathrm{H}), 7.60(\mathrm{t}, J=7.3 \mathrm{~Hz}, 1 \mathrm{H}), 7.50$ $(\mathrm{t}, J=7.3 \mathrm{~Hz}, 1 \mathrm{H}), 7.45-7.39(\mathrm{~m}, 1 \mathrm{H}), 7.36(\mathrm{~d}, J=10.6 \mathrm{~Hz}, 1 \mathrm{H})$, 7.18-7.03 (m, 2H).

3.1.4. General procedure for the preparation of $1 \mathrm{a}-\mathrm{d}$. To a stirred solution of 10a-d (1 equivalent) in dry acetonitrile was added $\mathrm{SbCl}_{3}$ (0.5 equivalents). The reaction mixture was heated at $80{ }^{\circ} \mathrm{C}$. Upon completion of the process (monitored by TLC), the reaction mixture was decomposed with water, extracted with EtOAc, and washed with saturated aqueous $\mathrm{NaCl}$. The combined organic phases were dried over $\mathrm{Na}_{2} \mathrm{SO}_{4}$ and concentrated under reduced pressure. The residue was purified by silica gel column chromatography to afford 1a-d as yellow solids.

3.1.5. 2-Phenyl-2,3-dihydrobenzo[h] quinolin-4(1H)-one (1a). Yellow solid; yield: $53 \% ;{ }^{1} \mathrm{H}$ NMR $\left(400 \mathrm{MHz}, \mathrm{CDCl}_{3}\right) \delta 7.85(\mathrm{~d}, J=$ $8.7 \mathrm{~Hz}, 1 \mathrm{H}), 7.73(\mathrm{t}, J=9.1 \mathrm{~Hz}, 2 \mathrm{H}), 7.54-7.46(\mathrm{~m}, 3 \mathrm{H}), 7.43-7.32$ $(\mathrm{m}, 4 \mathrm{H}), 7.14(\mathrm{~d}, J=8.7 \mathrm{~Hz}, 1 \mathrm{H}), 5.34(\mathrm{~s}, 1 \mathrm{H}), 4.83(\mathrm{dd}, J=14.2$, $3.8 \mathrm{~Hz}, 1 \mathrm{H}), 3.01-2.90(\mathrm{~m}, 1 \mathrm{H}), 2.79(\mathrm{dd}, J=16.2,3.7 \mathrm{~Hz}, 1 \mathrm{H})$; HRMS (ESI) calcd for $\mathrm{C}_{19} \mathrm{H}_{16} \mathrm{NO}[\mathrm{M}+\mathrm{H}]^{+} 274.1232$, found 274.1214. HPLC purity $=99.1 \%$.

3.1.6. 2-(3,4,5-Trimethoxyphenyl)-2,3-dihydrobenzo[h]quinolin-4(1H)-one (1b). Yellow solid; yield: 46\%; ${ }^{1} \mathrm{H}$ NMR (400 $\left.\mathrm{MHz}, \mathrm{CDCl}_{3}\right) \delta 7.90(\mathrm{~d}, J=8.7 \mathrm{~Hz}, 1 \mathrm{H}), 7.80(\mathrm{dd}, J=17.9$, $8.2 \mathrm{~Hz}, 2 \mathrm{H}), 7.58(\mathrm{t}, J=7.4 \mathrm{~Hz}, 1 \mathrm{H}), 7.47(\mathrm{t}, J=7.8 \mathrm{~Hz}, 1 \mathrm{H}), 7.21$ $(\mathrm{d}, J=8.7 \mathrm{~Hz}, 1 \mathrm{H}), 6.75(\mathrm{~s}, 2 \mathrm{H}), 5.39(\mathrm{~s}, 1 \mathrm{H}), 4.80(\mathrm{dd}, J=14.4$, $3.2 \mathrm{~Hz}, 1 \mathrm{H}), 3.89$ (s, 6H), 3.87 (s, 3H), 3.04-2.94 (m, 1H), 2.88 $2.79(\mathrm{~m}, 1 \mathrm{H})$; HRMS (ESI) calcd for $\mathrm{C}_{22} \mathrm{H}_{22} \mathrm{NO}_{4}[\mathrm{M}+\mathrm{H}]^{+}$ 364.1549 , found 364.1528. HPLC purity $=99.3 \%$.

3.1.7. 2-(2-Fluorophenyl)-2,3-dihydrobenzo[h]quinolin-4(1H)one (1c). Yellow solid; yield: $58 \%$; ${ }^{1} \mathrm{H}$ NMR (400 $\mathrm{MHz}, \mathrm{CDCl}_{3}$ ) $\delta 7.90(\mathrm{~d}, J=8.5 \mathrm{~Hz}, 1 \mathrm{H}), 7.86-7.74(\mathrm{~m}, 2 \mathrm{H}), 7.67-7.55(\mathrm{~m}, 2 \mathrm{H})$, 7.51-7.44 (m, 1H), 7.38-7.30 (m, 1H), 7.23-7.17 (m, 2H), 7.15-7.09 (m, 1H), 5.42 (s, 1H), 5.35-5.22 (m, 1H), 3.17-2.85 (m, 2H); HRMS (ESI) calcd for $\mathrm{C}_{19} \mathrm{H}_{15} \mathrm{FNO}[\mathrm{M}+\mathrm{H}]^{+}$292.1138, found 292.1121. HPLC purity $=95.6 \%$.

3.1.8. 2-(3-Fluorophenyl)-2,3-dihydrobenzo[h]quinolin-4(1H)one (1d). Yellow solid; yield: $51 \%$; ${ }^{1} \mathrm{H}$ NMR (400 $\mathrm{MHz}, \mathrm{CDCl}_{3}$ ) $\delta 7.90(\mathrm{~d}, J=8.7 \mathrm{~Hz}, 1 \mathrm{H}), 7.80(\mathrm{dd}, J=12.6,8.5 \mathrm{~Hz}, 2 \mathrm{H}), 7.58(\mathrm{t}, J=$ $7.3 \mathrm{~Hz}, 1 \mathrm{H}), 7.52-7.45$ (m, 1H), 7.44-7.36 (m, 1H), 7.32-7.25 (m, $2 \mathrm{H}), 7.22(\mathrm{~d}, J=9.0 \mathrm{~Hz}, 1 \mathrm{H}), 7.14-7.02(\mathrm{~m}, 1 \mathrm{H}), 5.38(\mathrm{~s}, 1 \mathrm{H}), 4.95-$ $4.82(\mathrm{~m}, 1 \mathrm{H}), 3.07-2.78(\mathrm{~m}, 2 \mathrm{H})$; HRMS (ESI) calcd for $\mathrm{C}_{19} \mathrm{H}_{15} \mathrm{FNO}$ $[\mathrm{M}+\mathrm{H}]^{+}$292.1138, found 292.1120. HPLC purity $=100.0 \%$.

3.1.9. General procedure for the preparation of $11 \mathrm{a}, \mathrm{b}$. Sodium hydroxide $(0.5 \mathrm{ml}, 10 \%)$ and hydrogen peroxide $(1.2 \mathrm{ml}$, $30 \%$ ) were added to a suspension of 10a-d ( $2 \mathrm{mmol})$ in $\mathrm{CH}_{3} \mathrm{OH}$ $(10 \mathrm{ml})$. The reaction mixture was stirred at room temperature for $48 \mathrm{~h}$, and then the yellow crystals were filtered off to give 11a,b in excellent yields. Representative spectral data of 11a, (1amino-2-naphthyl)(3-phenyloxiran-2-yl)methanone: ${ }^{1} \mathrm{H} \quad \mathrm{NMR}$ $\left(400 \mathrm{MHz}, \mathrm{DMSO}-d_{6}\right) \delta 8.74(\mathrm{~s}, 2 \mathrm{H}), 8.42(\mathrm{~d}, J=8.2 \mathrm{~Hz}, 1 \mathrm{H}), 7.76$ $(\mathrm{dd}, J=8.5,4.6 \mathrm{~Hz}, 2 \mathrm{H}), 7.63(\mathrm{t}, J=7.4 \mathrm{~Hz}, 1 \mathrm{H}), 7.55-7.33(\mathrm{~m}$, $6 \mathrm{H}), 6.99(\mathrm{~d}, J=9.1 \mathrm{~Hz}, 1 \mathrm{H}), 4.77(\mathrm{~d}, J=2.0 \mathrm{~Hz}, 1 \mathrm{H}), 4.12(\mathrm{~d}, J=$ $2.0 \mathrm{~Hz}, 1 \mathrm{H})$.

3.1.10. General procedure for the preparation of $2 a, b$. To a stirred solution of 11a,b (1 equivalent) in dry DCM was added $\mathrm{AlCl}_{3}$ ( 0.5 equivalents). The reaction mixture was stirred at room temperature overnight, and then the reaction mixture was decomposed with water, extracted with EtOAc and washed with saturated aqueous $\mathrm{NaCl}$. The combined organic layers were dried over $\mathrm{Na}_{2} \mathrm{SO}_{4}$ and concentrated under reduced pressure. The residue was purified by silica gel column chromatography to afford $\mathbf{2 a , b}$ as yellow solids. 
3.1.11. $(2 S, 3 R) \quad 3$-Hydroxy-2-phenyl-2,3-dihydrobenzo[ $h]$ quinolin-4(1H)-one (2a). Yellow solid; yield: 53\%; ${ }^{1} \mathrm{H}$ NMR $(400$ MHz, DMSO- $\left.d_{6}\right) \delta 8.32(\mathrm{~d}, J=8.2 \mathrm{~Hz}, 1 \mathrm{H}), 7.80(\mathrm{~s}, 2 \mathrm{H}), 7.64(\mathrm{~d}$, $J=8.3 \mathrm{~Hz}, 1 \mathrm{H}), 7.49(\mathrm{t}, J=7.5 \mathrm{~Hz}, 1 \mathrm{H}), 7.42-7.32(\mathrm{~m}, 3 \mathrm{H}), 7.31-$ $7.22(\mathrm{~m}, 3 \mathrm{H}), 6.46(\mathrm{~s}, 1 \mathrm{H}), 5.91(\mathrm{~d}, J=6.9 \mathrm{~Hz}, 1 \mathrm{H}), 4.31(\mathrm{t}, J=$ $6.5 \mathrm{~Hz}, 1 \mathrm{H}), 4.11$ (d, $J=6.3 \mathrm{~Hz}, 1 \mathrm{H}$ ); HRMS (ESI) calcd for $\mathrm{C}_{19} \mathrm{H}_{16} \mathrm{NO}_{2}[\mathrm{M}+\mathrm{H}]^{+} 290.1181$, found 290.1160. HPLC purity $=$ 99.4\%.

3.1.12. (2S,3R) 3-Hydroxy-2-(3,4,5-trimethoxyphenyl)-2,3dihydrobenzo[h]quinolin-4(1H)-one (2b). Yellow solid; yield: $48 \% ;{ }^{1} \mathrm{H}$ NMR $\left(400 \mathrm{MHz}, \mathrm{CDCl}_{3}\right) \delta 7.88(\mathrm{~d}, J=8.8 \mathrm{~Hz}, 1 \mathrm{H}), 7.84-$ $7.78(\mathrm{~m}, 2 \mathrm{H}), 7.63(\mathrm{t}, J=7.6 \mathrm{~Hz}, 1 \mathrm{H}), 7.54-7.48(\mathrm{~m}, 1 \mathrm{H}), 7.24(\mathrm{~s}$, $1 \mathrm{H}), 6.87(\mathrm{~s}, 2 \mathrm{H}), 5.40(\mathrm{~s}, 1 \mathrm{H}), 4.58(\mathrm{~d}, J=7.3 \mathrm{~Hz}, 1 \mathrm{H}), 4.01(\mathrm{~s}$, 1H), 3.98 (s, 1H), 3.93 (s, 6H), 3.90 (s, 3H); HRMS (ESI) calcd for $\mathrm{C}_{22} \mathrm{H}_{22} \mathrm{NO}_{5}[\mathrm{M}+\mathrm{H}]^{+} 380.1498$, found 380.1480 . HPLC purity $=$ $99.2 \%$.

3.1.13. Procedure for the preparation of 1-amino-2naphthoic acid (12). To a stirred solution of $7(1.68 \mathrm{~g}, 10$ $\mathrm{mmol})$ in EtOH $(50 \mathrm{ml})$ was added $\mathrm{NaOH}$ solution $(20 \%, 16 \mathrm{ml})$. The mixture was heated to reflux for $10 \mathrm{~h}$. After cooling, the EtOH was removed under reduced pressure and water $(100 \mathrm{ml})$ was added. The mixture was extracted with EtOAc twice, and the organic layers were discarded. Then the water layer was brought to $\mathrm{pH} 6.5$ with conc. aqueous $\mathrm{HCl}$ to furnish a white precipitate. The solid was collected and dried under vacuum to give 12 in $62 \%$ yield, which was used in the next step without further purification. ${ }^{1} \mathrm{H}$ NMR (400 MHz, $\left.\mathrm{CD}_{3} \mathrm{OD}\right) \delta 8.15$ (d, $J=8.3 \mathrm{~Hz}$, $1 \mathrm{H}), 7.82(\mathrm{~d}, J=8.9 \mathrm{~Hz}, 1 \mathrm{H}), 7.71(\mathrm{~d}, J=7.9 \mathrm{~Hz}, 1 \mathrm{H}), 7.53(\mathrm{t}, J=$ $7.5 \mathrm{~Hz}, 1 \mathrm{H}), 7.44$ (t, $J=7.6 \mathrm{~Hz}, 1 \mathrm{H}), 6.99$ (d, $J=8.7 \mathrm{~Hz}, 1 \mathrm{H})$.

3.1.14. General procedure for the preparation of $14 \mathrm{a}-\mathrm{d}$. To a solution of $12(374 \mathrm{mg}, 2 \mathrm{mmol})$ in DMF $(5 \mathrm{ml}), \mathrm{K}_{2} \mathrm{CO}_{3}$ (414 mg, $3 \mathrm{mmol}$ ) was added. The mixture was heated to $90{ }^{\circ} \mathrm{C}$ and stirred for $1.5 \mathrm{~h}$. After cooling to room temperature, 2bromo-1-arylethan-1-one 13a-d ( $2 \mathrm{mmol})$ was added. Then, the reaction mixture was heated to $60{ }^{\circ} \mathrm{C}$ and stirred for $2 \mathrm{~h}$. After that, the mixture was poured into ice water $(20 \mathrm{ml})$. The filtered precipitate, after washing with water and drying, afforded 14ad in excellent yields as white solids. Representative spectral data of 14a, (2-oxo-2-phenylethyl-1-amino-2-naphthoate): ${ }^{1} \mathrm{H}$ NMR $\left(400 \mathrm{MHz}, \mathrm{DMSO}-d_{6}\right) \delta 8.36(\mathrm{~d}, J=8.6 \mathrm{~Hz}, 1 \mathrm{H}), 8.04(\mathrm{~d}, J=$ $7.5 \mathrm{~Hz}, 2 \mathrm{H}), 7.86(\mathrm{~d}, J=8.7 \mathrm{~Hz}, 1 \mathrm{H}), 7.81(\mathrm{~s}, 1 \mathrm{H}), 7.79(\mathrm{~s}, 2 \mathrm{H})$, $7.72(\mathrm{t}, J=7.5 \mathrm{~Hz}, 1 \mathrm{H}), 7.67-7.56(\mathrm{~m}, J=7.3 \mathrm{~Hz}, 3 \mathrm{H}), 7.51(\mathrm{t}, J=$ $8.8 \mathrm{~Hz}, 1 \mathrm{H}), 7.06(\mathrm{~d}, J=8.8 \mathrm{~Hz}, 1 \mathrm{H}), 5.72(\mathrm{~s}, 2 \mathrm{H})$.

3.1.15. General procedure for the preparation of $3 a-d$. Compound 14a-d was added to polyphosphoric acid (PPA) and stirred at $120{ }^{\circ} \mathrm{C}$ for $3 \mathrm{~h}$. After that, the mixture was neutralized by aqueous $\mathrm{NaOH}$. The resulting mixture was extracted with EtOAc several times. The combined organic extracts were washed with saturated aqueous $\mathrm{NaCl}$, dried over $\mathrm{Na}_{2} \mathrm{SO}_{4}$, and the solvent removed under vacuum. The residue was purified by silica gel column chromatography to afford 3a-d as purple solids.

3.1.16. 3-Hydroxy-2-phenylbenzo[h]quinolin-4(1H)-one (3a). Purple solid; yield: $40 \%$; ${ }^{1} \mathrm{H}$ NMR (400 MHz, DMSO- $\left.d_{6}\right) \delta 11.47$ (s, $1 \mathrm{H}), 8.97$ (s, 1H), 8.17-8.09 (m, 1H), 8.03-7.93 (m, 1H), 7.78 (s, 2H), 7.72-7.59 (m, 3H), $7.54(\mathrm{~m}, 4 \mathrm{H})$; HRMS (ESI) calcd for
$\mathrm{C}_{19} \mathrm{H}_{14} \mathrm{NO}_{2}[\mathrm{M}+\mathrm{H}]^{+}$288.1025, found 288.1016. HPLC purity $=$ 99.0\%.

3.1.17. 2-(2-Fluorophenyl)-3-hydroxybenzo[h]quinolin-4(1H)one (3b). Purple solid; yield: $32 \% ;{ }^{1} \mathrm{H}$ NMR (400 MHz, DMSO- $d_{6}$ ) $\delta 11.73(\mathrm{~s}, 1 \mathrm{H}), 8.99-8.89(\mathrm{~m}, 1 \mathrm{H}), 8.15(\mathrm{~d}, J=8.8 \mathrm{~Hz}, 1 \mathrm{H}), 8.02(\mathrm{~m}$, 1H), $7.91(\mathrm{~s}, 1 \mathrm{H}), 7.81-7.75(\mathrm{~m}, 1 \mathrm{H}), 7.68-7.64(\mathrm{~m}, 2 \mathrm{H}), 7.62-7.56$ (m, 2H), 7.37 (d, $J=7.0 \mathrm{~Hz}, 1 \mathrm{H}), 7.27-7.23$ (m, 1H); HRMS (ESI) calcd for $\mathrm{C}_{19} \mathrm{H}_{13} \mathrm{FNO}_{2}[\mathrm{M}+\mathrm{H}]^{+}$306.0930, found 306.0910. HPLC purity $=100.0 \%$.

3.1.18. 3-Hydroxy-2-(4-hydroxyphenyl)benzo[h]quinolin4(1H)-one (3c). Purple solid; yield: 39\%; ${ }^{1} \mathrm{H}$ NMR $(400 \mathrm{MHz}$, DMSO- $\left.d_{6}\right) \delta 11.32(\mathrm{~s}, 1 \mathrm{H}), 9.85(\mathrm{~s}, 1 \mathrm{H}), 8.99(\mathrm{~d}, J=7.7 \mathrm{~Hz}, 1 \mathrm{H})$, $8.16(\mathrm{~d}, J=8.9 \mathrm{~Hz}, 1 \mathrm{H}), 8.01(\mathrm{~d}, J=7.2 \mathrm{~Hz}, 1 \mathrm{H}), 7.80-7.55(\mathrm{~m}$, $6 \mathrm{H}), 6.96(\mathrm{~d}, J=8.2 \mathrm{~Hz}, 2 \mathrm{H})$; HRMS (ESI) calcd for $\mathrm{C}_{19} \mathrm{H}_{14} \mathrm{NO}_{3}$ $[\mathrm{M}+\mathrm{H}]^{+}$304.0974, found 304.0955. HPLC purity $=91.5 \%$.

3.1.19. 2-(4-Fluorophenyl)-3-hydroxybenzo[h]quinolin-4(1H)one (3d). Purple solid; yield: $41 \%$; ${ }^{1} \mathrm{H}$ NMR (400 MHz, DMSO- $d_{6}$ ) $\delta 11.47(\mathrm{~s}, 1 \mathrm{H}), 8.99(\mathrm{~s}, 1 \mathrm{H}), 8.21-8.11(\mathrm{~m}, 1 \mathrm{H}), 8.08-8.00(\mathrm{~m}, 1 \mathrm{H})$, 7.88 (s, 2H), 7.76-7.55 (m, 4H), 7.47-7.36 (m, 2H); HRMS (ESI) calcd for $\mathrm{C}_{19} \mathrm{H}_{13} \mathrm{FNO}_{2}[\mathrm{M}+\mathrm{H}]^{+}$306.0930, found 306.0915. HPLC purity $=95.3 \%$.

3.1.20. General procedure for the preparation of ethyl benzoylacetate derivatives $17 \mathbf{a}-\mathbf{j}$. To a mixture of benzoic acids 16a-j $(10 \mathrm{mmol})$ and carbonyldiimidazole $(11 \mathrm{mmol})$, dry THF was added. The reaction mixture was stirred at room temperature for $6 \mathrm{~h}$, and then a mixture of ethyl potassium malonate $(15,10 \mathrm{mmol}$ ) [which had been prepared from ethyl hydrogen malonate (10 g) and $\mathrm{KOH}(4 \mathrm{~g})$ in absolute ethyl alcohol $40 \mathrm{ml}$ ], $\mathrm{MgCl}_{2}(20 \mathrm{mmol})$ and triethylamine $(3.4 \mathrm{ml})$ were added. The reaction mixture was stirred at room temperature for $24 \mathrm{~h}$. Evaporation of the solvent provided a residue that was diluted in $\mathrm{HCl}$ aqueous solution $(2 \mathrm{M})$. The mixture was extracted with EtOAc. The combined organic layers were washed with saturated aqueous $\mathrm{NaHCO}_{3}$, saturated aqueous $\mathrm{NaCl}$, and then dried over $\mathrm{Na}_{2} \mathrm{SO}_{4}$. Evaporation of the solvent provided a crude product that was purified by silica gel column chromatography to give $\mathbf{1 7 a - j}$ as an oil in good yields. They could be used in the next step without further purification.

3.1.21. General procedure for the preparation of $3 \mathrm{e}, 4 \mathrm{a}$ and $\mathbf{5 a - j}$. A mixture of naphthylamine derivative ( 1 equivalent), ethyl benzoylacetate derivatives $\mathbf{1 7 a - j}$ ( 2 equivalents), and PPA was heated at $130{ }^{\circ} \mathrm{C}$ with stirring. After the reaction was completed, the mixture was cooled to room temperature and neutralized with aqueous $\mathrm{NaOH}$. The resulting mixture was extracted with EtOAc. The combined organic extracts were washed with saturated $\mathrm{NaCl}$ aqueous, dried over $\mathrm{Na}_{2} \mathrm{SO}_{4}$ and the solvent removed under vacuum. Residues were purified by silica gel column chromatography to give the title compounds.

3.1.22. 2-Phenylbenzo[h]quinolin-4(1H)-one (3e). Pale white solid; yield: $38 \% ;{ }^{1} \mathrm{H}$ NMR (400 MHz, DMSO- $\left.d_{6}\right) \delta 12.24$ (s, $1 \mathrm{H}), 8.96(\mathrm{~d}, J=6.1 \mathrm{~Hz}, 1 \mathrm{H}), 7.97(\mathrm{~d}, J=7.4 \mathrm{~Hz}, 1 \mathrm{H}), 7.74-7.65$ $(\mathrm{m}, 2 \mathrm{H}), 7.65-7.54(\mathrm{~m}, 4 \mathrm{H}), 7.54-7.49(\mathrm{~m}, 2 \mathrm{H}), 7.46-7.28(\mathrm{~m}$, $1 \mathrm{H}), 6.53(\mathrm{~s}, 1 \mathrm{H})$; HRMS (ESI) calcd for $\mathrm{C}_{19} \mathrm{H}_{14} \mathrm{NO}[\mathrm{M}+\mathrm{H}]^{+}$ 272.1075 , found 272.1052 . HPLC purity $=98.9 \%$.

3.1.23. 2-Phenylbenzo[ $\boldsymbol{h}]$ quinolin-4-ol (4a). Pale white solid; yield: $60 \%$; ${ }^{1} \mathrm{H}$ NMR (400 MHz, DMSO- $\left.d_{6}\right) \delta 9.28(\mathrm{~s}, 1 \mathrm{H})$, $8.23(\mathrm{~s}, 2 \mathrm{H}), 8.10(\mathrm{~d}, J=8.5 \mathrm{~Hz}, 1 \mathrm{H}), 8.01(\mathrm{~s}, 1 \mathrm{H}), 7.84(\mathrm{~d}, J=$ 
$8.5 \mathrm{~Hz}, 1 \mathrm{H}), 7.74(\mathrm{~s}, 2 \mathrm{H}), 7.63-7.55(\mathrm{~m}, 2 \mathrm{H}), 7.54-7.29(\mathrm{~m}, 2 \mathrm{H})$; HRMS (ESI) calcd for $\mathrm{C}_{19} \mathrm{H}_{14} \mathrm{NO}[\mathrm{M}+\mathrm{H}]^{+} 272.1075$, found 272.1052. HPLC purity $=98.2 \%$.

3.1.24. 6,10-Dimethoxy-2-phenylbenzo[h]quinolin-4(1H)one (5a). Brown solid; yield: $22 \%$; ${ }^{1} \mathrm{H}$ NMR $(400 \mathrm{MHz}$, DMSO$\left.d_{6}\right) \delta 11.65(\mathrm{~s}, 1 \mathrm{H}), 7.78(\mathrm{~d}, J=8.3 \mathrm{~Hz}, 1 \mathrm{H}), 7.65-7.50(\mathrm{~m}, 6 \mathrm{H})$, $7.29(\mathrm{~d}, J=7.9 \mathrm{~Hz}, 1 \mathrm{H}), 6.70(\mathrm{~s}, 1 \mathrm{H}), 6.49(\mathrm{~s}, 1 \mathrm{H}), 4.16(\mathrm{~s}, 3 \mathrm{H})$, $3.71(\mathrm{~s}, 3 \mathrm{H})$; HRMS (ESI) calcd for $\mathrm{C}_{21} \mathrm{H}_{18} \mathrm{NO}_{3}[\mathrm{M}+\mathrm{H}]^{+}$ 332.1287 , found 332.1271 . HPLC purity $=99.1 \%$.

3.1.25. 2-(2-Fluorophenyl)-6,10-dimethoxybenzo[h]quinolin$\mathbf{4}(\mathbf{1 H})$-one (5b). Brown solid; yield: $17 \% ;{ }^{1} \mathrm{H}$ NMR $(400 \mathrm{MHz}$, DMSO- $\left.d_{6}\right) \delta 11.81(\mathrm{~s}, 1 \mathrm{H}), 7.92-7.83(\mathrm{~m}, 1 \mathrm{H}), 7.73-7.67(\mathrm{~m}, 1 \mathrm{H})$, 7.65-7.59 (m, 1H), 7.59-7.51 (m, 1H), 7.49-7.42 (m, 2H), 7.41$7.35(\mathrm{~m}, 1 \mathrm{H}), 6.61(\mathrm{~s}, 1 \mathrm{H}), 6.53(\mathrm{~s}, 1 \mathrm{H}), 4.21(\mathrm{~s}, 3 \mathrm{H}), 3.74(\mathrm{~s}, 3 \mathrm{H})$; HRMS (ESI) calcd for $\mathrm{C}_{21} \mathrm{H}_{17} \mathrm{FNO}_{3}[\mathrm{M}+\mathrm{H}]^{+} 350.1192$, found 350.1174 . HPLC purity $=98.0 \%$.

3.1.26. 2-(3-Fluorophenyl)-6,10-dimethoxybenzo[h]quinolin4(1H)-one (5c). Brown solid; yield: $19 \% ;{ }^{1} \mathrm{H}$ NMR $(400 \mathrm{MHz}$, DMSO- $\left.d_{6}\right) \delta 11.76(\mathrm{~s}, 1 \mathrm{H}), 7.86(\mathrm{~d}, J=8.5 \mathrm{~Hz}, 1 \mathrm{H}), 7.71-7.59(\mathrm{~m}$, 2H), 7.48-7.32 (m, 4H), $6.73(\mathrm{~s}, 1 \mathrm{H}), 6.56(\mathrm{~s}, 1 \mathrm{H}), 4.19(\mathrm{~s}, 3 \mathrm{H}), 3.77$ (s, 3H); HRMS (ESI) calcd for $\mathrm{C}_{21} \mathrm{H}_{17} \mathrm{FNO}_{3}[\mathrm{M}+\mathrm{H}]^{+}$350.1192, found 350.1180 . HPLC purity $=100.0 \%$.

3.1.27. 2-(3-Chlorophenyl)-6,10-dimethoxybenzo[h]quinolin4(1H)-one (5d). Brown solid; yield: $15 \% ;{ }^{1} \mathrm{H}$ NMR $(400 \mathrm{MHz}$, DMSO- $\left.d_{6}\right) \delta 11.65(\mathrm{~s}, 1 \mathrm{H}), 7.78(\mathrm{~d}, J=8.2 \mathrm{~Hz}, 1 \mathrm{H}), 7.69-7.57(\mathrm{~m}$, $4 \mathrm{H}), 7.52(\mathrm{~s}, 1 \mathrm{H}), 7.32(\mathrm{~d}, J=7.9 \mathrm{~Hz}, 1 \mathrm{H}), 6.61(\mathrm{~s}, 1 \mathrm{H}), 6.52(\mathrm{~s}, 1 \mathrm{H})$, $4.15(\mathrm{~s}, 3 \mathrm{H}), 3.72(\mathrm{~s}, 3 \mathrm{H})$; HRMS (ESI) calcd for $\mathrm{C}_{21} \mathrm{H}_{17} \mathrm{ClNO}_{3}[\mathrm{M}+$ $\mathrm{H}]^{+}$366.0897, found 366.0876. HPLC purity $=99.2 \%$.

3.1.28. 2-(3-Bromophenyl)-6,10-dimethoxybenzo[h]quinolin4(1H)-one (5e). Brown solid; yield: $18 \%$; ${ }^{1} \mathrm{H}$ NMR $(400 \mathrm{MHz}$, DMSO- $\left.d_{6}\right) \delta 11.75(\mathrm{~s}, 1 \mathrm{H}), 7.93-7.87(\mathrm{~m}, 1 \mathrm{H}), 7.86-7.79(\mathrm{~m}, 1 \mathrm{H})$, $7.76(\mathrm{~s}, 1 \mathrm{H}), 7.69-7.61(\mathrm{~m}, 1 \mathrm{H}), 7.58-7.53(\mathrm{~m}, 1 \mathrm{H}), 7.49(\mathrm{~s}, 1 \mathrm{H})$, $7.40-7.31(\mathrm{~m}, 1 \mathrm{H}), 6.69(\mathrm{~s}, 1 \mathrm{H}), 6.55(\mathrm{~s}, 1 \mathrm{H}), 4.18(\mathrm{~s}, 3 \mathrm{H}), 3.76(\mathrm{~s}$, $3 \mathrm{H}$ ); HRMS (ESI) calcd for $\mathrm{C}_{21} \mathrm{H}_{17} \mathrm{BrNO}_{3}[\mathrm{M}+\mathrm{H}]^{+} 410.0392$, found 410.0369. HPLC purity $=100.0 \%$.

3.1.29. 6,10-Dimethoxy-2-(3-methoxyphenyl)benzo[h]quinolin-4(1H)-one (5f). Brown solid; yield: $16 \% ;{ }^{1} \mathrm{H}$ NMR $(400 \mathrm{MHz}$, DMSO- $\left.d_{6}\right) \delta 11.61(\mathrm{~s}, 1 \mathrm{H}), 7.76(\mathrm{~d}, J=7.9 \mathrm{~Hz}, 1 \mathrm{H}), 7.58(\mathrm{t}, J=$ $7.2 \mathrm{~Hz}, 1 \mathrm{H}), 7.54-7.46(\mathrm{~m}, 1 \mathrm{H}), 7.26(\mathrm{~d}, J=7.4 \mathrm{~Hz}, 1 \mathrm{H}), 7.15-7.01$ $(\mathrm{m}, 3 \mathrm{H}), 6.73(\mathrm{~s}, 1 \mathrm{H}), 6.50(\mathrm{~s}, 1 \mathrm{H}), 4.14(\mathrm{~s}, 3 \mathrm{H}), 3.86(\mathrm{~s}, 3 \mathrm{H}), 3.71$ (s, 3H); HRMS (ESI) calcd for $\mathrm{C}_{22} \mathrm{H}_{20} \mathrm{NO}_{4}[\mathrm{M}+\mathrm{H}]^{+}$362.1392, found 362.1399. HPLC purity $=94.6 \%$.

3.1.30. 2-(4-Fluorophenyl)-6,10-dimethoxybenzo[h]quinolin4(1H)-one (5g). Brown solid; yield: $22 \% ;{ }^{1} \mathrm{H}$ NMR $(400 \mathrm{MHz}$, DMSO- $\left.d_{6}\right) \delta 11.73(\mathrm{~s}, 1 \mathrm{H}), 7.85(\mathrm{~d}, J=8.3 \mathrm{~Hz}, 1 \mathrm{H}), 7.69-7.58(\mathrm{~m}$, $3 \mathrm{H}), 7.42(\mathrm{t}, J=8.1 \mathrm{~Hz}, 2 \mathrm{H}), 7.35(\mathrm{~d}, J=7.8 \mathrm{~Hz}, 1 \mathrm{H}), 6.73(\mathrm{~s}, 1 \mathrm{H})$, $6.53(\mathrm{~s}, 1 \mathrm{H}), 4.18(\mathrm{~s}, 3 \mathrm{H}), 3.77(\mathrm{~s}, 3 \mathrm{H})$; HRMS (ESI) calcd for $\mathrm{C}_{21} \mathrm{H}_{17} \mathrm{FNO}_{3}[\mathrm{M}+\mathrm{H}]^{+} 350.1192$, found 350.1175 . HPLC purity $=$ 95.1\%.

3.1.31. 6,10-Dimethoxy-2-(4-methoxyphenyl)benzo[h]quinolin-4(1H)-one (5h). Brown solid; yield: $19 \%$; ${ }^{1} \mathrm{H}$ NMR $(400 \mathrm{MHz}$, DMSO- $\left.d_{6}\right) \delta 11.70(\mathrm{~s}, 1 \mathrm{H}), 7.85(\mathrm{~d}, J=8.4 \mathrm{~Hz}, 1 \mathrm{H}), 7.66(\mathrm{t}, J=$ $8.1 \mathrm{~Hz}, 1 \mathrm{H}), 7.50$ (d, $J=7.5 \mathrm{~Hz}, 2 \mathrm{H}), 7.34(\mathrm{~d}, J=7.4 \mathrm{~Hz}, 1 \mathrm{H}), 7.13$ $(\mathrm{d}, J=8.5 \mathrm{~Hz}, 2 \mathrm{H}), 6.86(\mathrm{~s}, 1 \mathrm{H}), 6.48(\mathrm{~s}, 1 \mathrm{H}), 4.18(\mathrm{~s}, 3 \mathrm{H}), 3.86(\mathrm{~s}$, $3 \mathrm{H}), 3.78(\mathrm{~s}, 3 \mathrm{H})$; HRMS (ESI) calcd for $\mathrm{C}_{22} \mathrm{H}_{20} \mathrm{NO}_{4}[\mathrm{M}+\mathrm{H}]^{+}$ 362.1392 , found 362.1376 . HPLC purity $=95.6 \%$.
3.1.32. 6,10-Dimethoxy-2-(4-(trifluoromethyl)phenyl)benzo [h]quinolin-4(1H)-one (5i). Brown solid; yield: $21 \% ;{ }^{1} \mathrm{H}$ NMR $\left(400 \mathrm{MHz}, \mathrm{DMSO}-d_{6}\right) \delta 11.75(\mathrm{~s}, 1 \mathrm{H}), 7.94(\mathrm{~d}, J=7.4 \mathrm{~Hz}, 2 \mathrm{H}), 7.84$ $(\mathrm{d}, J=8.0 \mathrm{~Hz}, 1 \mathrm{H}), 7.80(\mathrm{~d}, J=7.4 \mathrm{~Hz}, 2 \mathrm{H}), 7.66(\mathrm{t}, J=7.9 \mathrm{~Hz}$, $1 \mathrm{H}), 7.35(\mathrm{~d}, J=8.0 \mathrm{~Hz}, 1 \mathrm{H}), 6.66(\mathrm{~s}, 1 \mathrm{H}), 6.58(\mathrm{~s}, 1 \mathrm{H}), 4.18(\mathrm{~s}$, $3 \mathrm{H}), 3.76(\mathrm{~s}, 3 \mathrm{H})$; HRMS (ESI) calcd for $\mathrm{C}_{22} \mathrm{H}_{17} \mathrm{~F}_{3} \mathrm{NO}_{3}[\mathrm{M}+\mathrm{H}]^{+}$ 400.1161, found 400.1153. HPLC purity $=100.0 \%$.

3.1.33. 6,10-Dimethoxy-2-(3,4,5-trimethoxyphenyl)benzo[h] quinolin-4(1H)-one (5j). Brown solid; yield: $17 \% ;{ }^{1} \mathrm{H}$ NMR (400 MHz, DMSO- $\left.d_{6}\right) \delta 11.78(\mathrm{~s}, 1 \mathrm{H}), 7.86(\mathrm{~d}, J=8.4 \mathrm{~Hz}, 1 \mathrm{H}), 7.66(\mathrm{t}$, $J=8.0 \mathrm{~Hz}, 1 \mathrm{H}), 7.35(\mathrm{~d}, J=7.9 \mathrm{~Hz}, 1 \mathrm{H}), 6.97(\mathrm{~s}, 1 \mathrm{H}), 6.82(\mathrm{~s}, 2 \mathrm{H})$, $6.58(\mathrm{~s}, 1 \mathrm{H}), 4.17(\mathrm{~s}, 3 \mathrm{H}), 3.80(\mathrm{~s}, 6 \mathrm{H}), 3.79(\mathrm{~s}, 3 \mathrm{H}), 3.72(\mathrm{~s}, 3 \mathrm{H})$; HRMS (ESI) calcd for $\mathrm{C}_{24} \mathrm{H}_{24} \mathrm{NO}_{6}[\mathrm{M}+\mathrm{H}]^{+} 422.1604$, found 422.1579. HPLC purity $=99.2 \%$.

3.1.34. 4-Methoxy-2-phenylbenzo[ $h]$ quinoline (4b). Sodium hydride (120 mg, $5 \mathrm{mmol}$ ) was added to a solution of $4 \mathbf{a}(678 \mathrm{mg}$, $2.5 \mathrm{mmol}$ ) in $5 \mathrm{ml}$ of anhydrous DMF. The reaction mixture was stirred at room temperature for $15 \mathrm{~min}$ and methyl iodide (426 mg, $3 \mathrm{mmol}$ ) was added slowly. After being stirred for $2 \mathrm{~h}$, the mixture was poured into ice water. Filtering the precipitate after washing, drying and recrystallization from $\mathrm{CH}_{3} \mathrm{OH}$ afforded $\mathbf{4 b}$ as a pale white solid in $89 \%$ yield. ${ }^{1} \mathrm{H}$ NMR $(400 \mathrm{MHz}$, DMSO- $\left.d_{6}\right) \delta 9.34(\mathrm{~d}, J=6.5 \mathrm{~Hz}, 1 \mathrm{H}), 8.46(\mathrm{~d}, J=7.2 \mathrm{~Hz}, 2 \mathrm{H})$, 8.14-7.97 (m, 2H), 7.90 (d, $J=8.8 \mathrm{~Hz}, 1 \mathrm{H}), 7.83-7.69(\mathrm{~m}, 3 \mathrm{H})$, $7.64-7.57$ (m, 2H), 7.54 (d, $J=6.9 \mathrm{~Hz}, 1 \mathrm{H}), 4.21$ (s, 3H); HRMS (ESI) calcd for $\mathrm{C}_{20} \mathrm{H}_{15} \mathrm{NO}[\mathrm{M}+\mathrm{H}]^{+} 286.1232$, found 286.1245. HPLC purity $=98.4 \%$.

\subsection{Enzyme assays}

The recombinant human CYP1B1, CYP1A1, and CYP1A2 enzymes, each equipped with $\mathrm{P} 450$ reductase (Supersomes), were purchased from BD Genetest. 7-Ethoxyresorufin (7-ER) was obtained from Sigma-Aldrich. NADP ${ }^{+}$, D-glucose-6-phosphate (G-6-P) and glucose-6-phosphate dehydrogenase (G-6-PD) were purchased from Biosharp. Other solvents and reagents used in the biological evaluation were of the highest quality and commercial availability. In the enzyme assay, FlexStation 3 apparatus was used for recording the fluorescence intensity with excitation and emission filters at 544 and $590 \mathrm{~nm}$, respectively.

The inhibitory activities of these prepared compounds against CYP1B1, CYP1A1, and CYP1A2 enzymes were determined using the EROD assay as reported earlier. ${ }^{29}$ All tested compounds were dissolved as stock solutions (10 mM) in DMSO and diluted to working solutions with a Tris- $\mathrm{HCl}$ buffer at $\mathrm{pH}$ 7.4 , and the final concentration of organic solvent was $<1 \%(\mathrm{v} / \mathrm{v})$ in all cases. Next, a mixture with a final volume of $200 \mu \mathrm{l}$ containing different concentrations of tested compounds (except positive and negative control wells), an enzyme source (20 fmol CYP1B1, 10 fmol CYP1A1 and 60 fmol CYP1A2), $150 \mathrm{nM}$ 7-ER, $1.3 \mathrm{mM} \mathrm{NADP}^{+}, 3.3 \mathrm{mM}$ G-6-P, $0.5 \mathrm{U} \mathrm{ml}^{-1}$ G-6-PD and $3.3 \mathrm{mM}$ $\mathrm{MgCl}_{2}$ was incubated in a black 96-well flat-bottomed microplate at $37{ }^{\circ} \mathrm{C}$ for different times (incubation time for CYP1B1, CYP1A1, and CYP1A2 was 35, 15 and $50 \mathrm{~min}$, respectively). Finally, the reaction was stopped by the addition of $100 \mu \mathrm{l}$ of methanol to all wells. The $\mathrm{IC}_{50}$ value for each compound was 
calculated with the GraphPad Prism Software (Version 5.0) using the non-linear regression formula: $\log$ (inhibitor) vs. normalized response-variable slope.

\subsection{Cancer cell growth inhibition assays}

RPMI-1640 culture medium, fetal bovine serum (FBS), and PBS (Hyclone) were purchased from Thermo Fisher Scientific. TCDD was obtained from AccuStandard. The MCF-7 cell line was cultured in RPMI 1640 medium with $10 \%$ FBS at $37{ }^{\circ} \mathrm{C}$ in a humidified atmosphere with $5 \% \mathrm{CO}_{2}$. MCF-7/1B1 cells were obtained by coincubation of parental MCF-7 cells with TCDD $(10 \mathrm{nM})$ for five days. The in vitro cytotoxicity was determined by combination of docetaxel with CYP1B1 inhibitors using the standard MTT assay ${ }^{30,31}$ Approximately 3000 cells, suspended in RPMI 1640 medium, were seeded into each well of a 96-well plate and incubated at $37{ }^{\circ} \mathrm{C}$ in a humidified atmosphere with $5 \% \mathrm{CO}_{2}$ for $24 \mathrm{~h}$. Then, six different concentrations of docetaxel with or without $10 \mu \mathrm{M}$ CYP1B1 inhibitors were added. Absorbance values were determined by a microplate reader at $490 \mathrm{~nm}$, and the $\mathrm{IC}_{50}$ values were calculated with the GraphPad Prism Software (Version 5.0) using the non-linear regression formula: $\log$ (inhibitor) vs. normalized response-variable slope. Student's $t$ tests were performed to compare their $\mathrm{IC}_{50}$ values using the PASW Statistics 18 software.

\subsection{Molecular docking}

In order to understand the binding mode and selectivity of the title compounds with both CYP1B1 and CYP1A2, we performed a molecule docking experiment using the docking program in MOE 2008 based on the crystal structures of CYP1B1 (PDB ID: 3PM0) and CYP1A2 (PDB ID: 2HI4). The initial 3D conformation of compounds $\mathbf{4 a}$ and $5 \mathbf{e}$ were optimized in ChemBio3D Ultra using the MM2 energy minimization method. All molecules were removed from the crystal structures before the experiment. Hydrogens and partial charges were added with the protonate 3D application. The residues within a radius of $8.0 \AA$ around the ligands were selected as docking sites. Docking parameters were kept at default, except for the first scoring function, where ASE Scoring was used instead of the default London dG. The best pose was characterized by the scoring results. To test whether the docking program is suitable for the ligands binding to human CYP1B1 and CYP1A2, the CYP1B1-ANF and CYP1A2ANF complexes (PDB ID: 3PM0 and PDB ID: 2HI4, respectively) were initially chosen as models. The results revealed that the docking compounds with ANF were comparable to their corresponding crystallographic structures. It was implied that the MOE docking program used is suitable for the current study.

\section{Conclusions}

The structural modification of $\alpha$-naphthoflavone gave new 2arylbenzo[ $h]$ quinolone derivatives, which exhibited varying potency and selectivity for CYP1B1 inhibition. Compared with ANF, replacement of the oxygen atom on the C-ring by a nitrogen atom caused a mild potency loss. However, this decreased inhibitory activity could be restored by enhancing the electron-density of the naphthalene part to intensify the $\pi-\pi$ stacking interaction. It is noteworthy that 2-arylbenzo[ $h]$ quinolones have shown a significantly increased selectivity toward CYP1B1 over CYP1A2. SAR analysis indicated that the double bond at the $\mathrm{C} 2-\mathrm{C} 3$ position is an indispensable structural feature for inhibitory action, while the hydroxyl group at the C3 position is an unfavorable structural characteristic. A molecular docking study disclosed that the most potent compound $\mathbf{5 e}$ tightly fitted the binding cavity of CYP1B1; hydrogen bonds, hydrophobic interactions and $\pi-\pi$ stacking interaction contribute to this high binding affinity, while these interactions were markedly reduced when it bound to CYP1A2. On the basis of the predicted $\operatorname{cog} P$ values, these target compounds may exhibit an improved water-solubility compared to ANF. Among them, $\mathbf{5 h}$ was found to be a potential compound to reverse CYP1B1-mediated drug resistance, since the cytotoxicity of docetaxel could be restored by pretreating MCF-7/1B1 cells with $5 \mathbf{h}$ at $10 \mu \mathrm{M}$. All of these results indicated that further development of these 2-arylbenzo[ $h]$ quinolones as more potent and specific CYP1B1 inhibitors may result in the discovery of promising candidates to reverse CYP1B1-mediated anticancerdrug resistance.

\section{Conflicts of interest}

There are no conflicts to declare.

\section{Acknowledgements}

This study was supported by the National Natural Science Foundation of China (Grant No. 21602132), the Shanghai Science and Technology Innovation Program (No. 15431900700) and the Shanghai Natural Science Fund (No. 16ZR1418100). Jinyun Dong also gratefully acknowledges the help and encouragement of Haixia Zhang.

\section{Notes and references}

1 J. Dong, Q. Zhang, Q. Cui, G. Huang, X. Pan and S. Li, ChemMedChem, 2016, 11, 2102-2118.

2 H. Doostdar, M. D. Burke and R. T. Mayer, Toxicology, 2000, 144, 31-38.

3 J. Mimura and Y. Fujii-Kuriyama, Biochim. Biophys. Acta, 2003, 1619, 263-268.

4 T. Muto, T. Watanabe, M. Moto, M. Okamura, Y. Kashida, Y. Kanai, K. Mitsumori and H. Endou, J. Toxicol. Pathol., 2003, 16, 287-290.

5 B. N. Zordoky and A. O. El-Kadi, Toxicol. In Vitro, 2010, 24, 863-871.

6 A. J. Lee, M. X. Cai, P. E. Thomas, A. H. Conney and B. T. Zhu, Endocrinology, 2003, 144, 3382-3398.

7 J. G. Liehr and M. J. Ricci, Proc. Natl. Acad. Sci. U. S. A., 1996, 93, 3294-3296.

8 J. Cui, Q. Meng, X. Zhang, Q. Cui, W. Zhou and S. Li, J. Med. Chem., 2015, 58, 3534-3547. 
9 G. I. Murray, M. C. Taylor, M. C. McFadyen, J. A. McKay, W. F. Greenlee, M. D. Burke and W. T. Melvin, Cancer Res., 1997, 57, 3026-3031.

10 R. D. Bruno and V. C. Njar, Bioorg. Med. Chem., 2007, 15, 5047-5060.

11 M. C. E. McFadyen, M. E. Cruickshank, I. D. Miller, H. McLeod, W. T. Melvin, N. E. Haites, D. Parkin and G. I. Murray, Br. J. Cancer, 2001, 85, 242-246.

12 L. H. Patterson and G. I. Murray, Curr. Pharm. Des., 2002, 8, 1335-1347.

13 T. Shimada, H. Yamazaki, M. Foroozesh, N. E. Hopkins, W. L. Alworth and F. P. Guengerich, Chem. Res. Toxicol., 1998, 11, 1048-1056.

14 M. C. McFadyen, H. L. McLeod, F. C. Jackson, W. T. Melvin, J. Doehmer and G. I. Murray, Biochem. Pharmacol., 2001, 62, 207-212.

15 A. Datta, N. Bhasin, H. Kim, M. Ranjan, B. Rider, Z. Y. A. Elmageed, D. Mondal, K. C. Agrawal and A. B. Abdel-Mageed, Cancer Lett., 2015, 362, 25-35.

16 A. Wang, U. Savas, C. D. Stout and E. F. Johnson, J. Biol. Chem., 2011, 286, 5736-5743.

17 S. Sansen, J. K. Yano, R. L. Reynald, G. A. Schoch, K. J. Griffin, C. D. Stout and E. F. Johnson, J. Biol. Chem., 2007, 282, 14348-14355.

18 A. A. Walsh, G. D. Szklarz and E. E. Scott, J. Biol. Chem., 2013, 288, 12932-12943.

19 Y. Tomioka, K. Ohkubo and M. Yamazaki, Chem. Pharm. Bull., 1985, 33, 1360-1366.
20 W. Zhang, K. F. Koehler, B. Harris, P. Skolnick and J. M. Cook, J. Med. Chem., 1994, 37, 745-757.

21 R. Bhattacharya, P. Kundu and G. Maiti, Synth. Commun., 2010, 40, 476-481.

22 J. A. Donnelly and D. F. Farrell, J. Org. Chem., 1990, 55, 17571761.

23 K. Machida, Y. Hirose, S. Fuse, T. Sugawara and T. Takahashi, Chem. Pharm. Bull., 2010, 58, 87-93.

24 J. Dong, Q. Zhang, G. Huang, Q. Meng and S. Li, Russ. J. Gen. Chem., 2017, 87, 837-841.

25 I. Chang, Y. Mitsui, S. Fukuhara, A. Gill, D. K. Wong, S. Yamamura, V. Shahryari, Z. L. Tabatabai, R. Dahiya and D. M. Shin, Oncotarget, 2015, 6, 7774-7787.

26 D. C. Spink, C. L. Hayes, N. R. Young, M. Christou, T. R. Sutter, C. R. Jefcoate and J. F. Gierthy, J. Steroid Biochem. Mol. Biol., 1994, 51, 251-258.

27 D. C. Spink, B. C. Spink, J. Q. Cao, J. A. DePasquale, B. T. Pentecost, M. J. Fasco, Y. Li and T. R. Sutter, Carcinogenesis, 1998, 19, 291-298.

28 V. Martinez, R. O'connor, Y. Liang and M. Clynes, Br. J. Cancer, 2008, 98, 564-570.

29 S. Yamaori, M. Kushihara, I. Yamamoto and K. Watanabe, Biochem. Pharmacol., 2010, 79, 1691-1698.

30 W. Zhou, Y. Peng and S. Li, Eur. J. Med. Chem., 2010, 45, 6005-6011.

31 A. Regielfutyra, M. Kusliśkiewicz, V. Sebastian, S. Irusta, M. Arruebo, A. Kyzioł and G. Stochel, RSC Adv., 2017, 7, 52398-52413. 